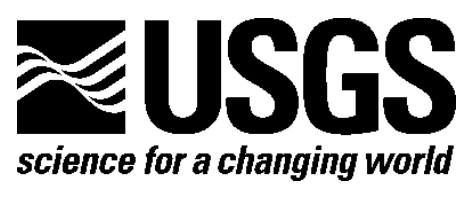

Prepared in cooperation with the Louisiana State University Agricultural Center

\title{
Preliminary Assessment of Bioengineered Fringing Shoreline Reefs in Grand Isle and Breton Sound, Louisiana
}

By Megan K. La Peyre, Lindsay Schwarting, and Shea Miller

Open-File Report 2013-1040

U.S. Department of the Interior

U.S. Geological Survey 


\section{U.S. Department of the Interior KEN SALAZAR, Secretary}

\section{U.S. Geological Survey \\ Suzette M. Kimball, Acting Director}

U.S. Geological Survey, Reston, Virginia: 2013

This and other USGS information products are available at http://store.usgs.gov/

U.S. Geological Survey

Box 25286, Denver Federal Center

Denver, CO 80225

To learn about the USGS and its information products visit http://www.usgs.gov/ 1-888-ASK-USGS

Any use of trade, product, or firm names is for descriptive purposes only and does not imply endorsement by the U.S. Government.

Although this report is in the public domain, permission must be secured from the individual copyright owners to reproduce any copyrighted materials contained within this report.

Suggested citation:

La Peyre, M.K., Schwarting, Lindsay, and Miller, Shea, 2013, Preliminary assessment of bioengineered fringing shoreline reefs in Grand Isle and Breton Sound, Louisiana: U.S. Geological Survey Open-File Report 2013-1040, 34 p. 


\section{Acknowledgments}

We thank the many people who were critical in completing field work, processing samples in the lab, maintaining and/or providing boats and boat support. This includes Louisiana State University Agricultural Center students and staff: Gary Decossas, Bran Wagner, Phil Westbrook, Aaron Honig, Austin Humphries, Steve Beck, Ben Eberline, Molly Rybovich, Jessica Furlong, Laura Brown, Mark Miller, Brandon Edwards, Cheryl Duplechain, Sandra Casas-Liste, Jerome La Peyre; The Nature Conservancy staff: Cindy Brown, Amy Smith-Kyle, Seth Blitch, Bryan Piazza, Jean Landry and Richard Martin. We thank John Supan and staff at Louisiana Department of Wildlife and Fisheries for allowing use of the Louisiana Sea Grant camp and the LDWF camp for lodging and use of the LDWF boat launch during the project. This final report was greatly improved through comments from Dr. Steven Scyphers and Dr. Lesley Baggett. This study was funded by a grant from The Nature Conservancy of Louisiana to the Louisiana State University Agricultural Center. This study was performed under the auspices of Louisiana State University IACUC protocols \#08-005 and 11-006. 


\section{Contents}

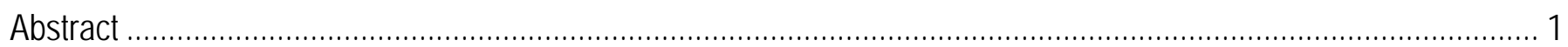

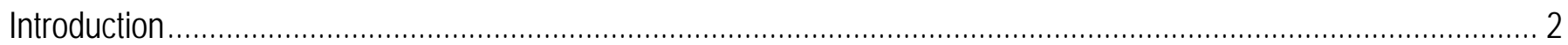

Study Area

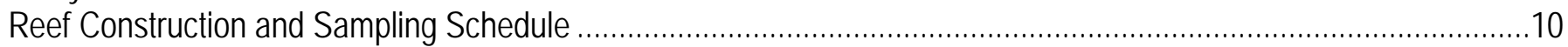

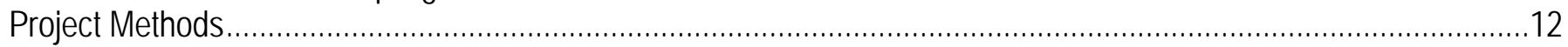

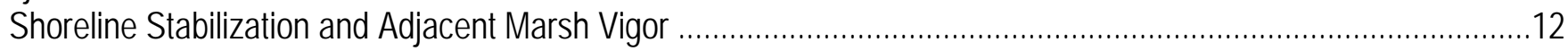

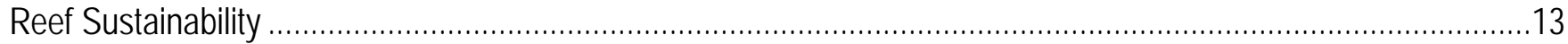

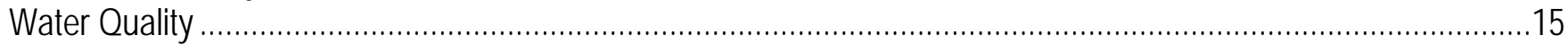

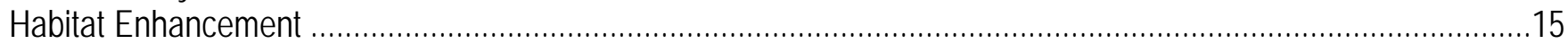

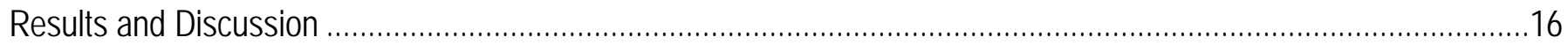

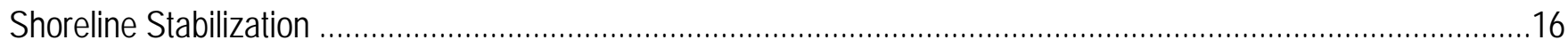

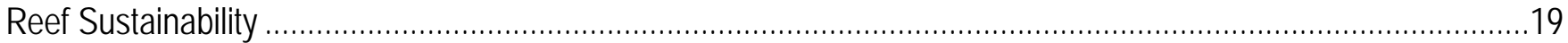

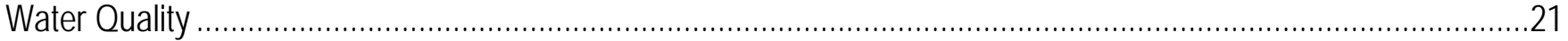

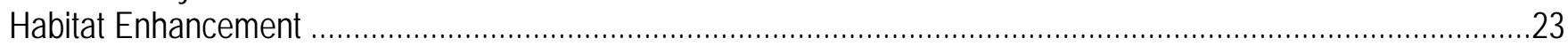

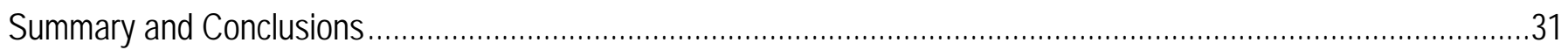

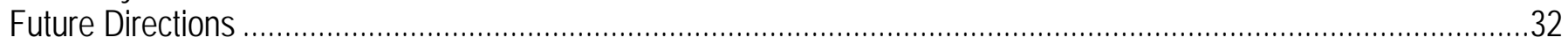

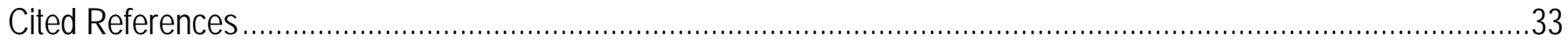

\section{Figures}

Figure 1. Location of three study sites where artificial reefs were built in coastal Louisiana. Grand Isle reef was completed in March 2011, and Lake Fortuna and Lake Eloi reefs were completed in December 2011 and January 2012, respectively.

Figure 2. One triangular ReefB $\mathrm{k}^{\mathrm{TM}}$ unit being installed in coastal Louisiana waters. Photograph used with permission of Amy Smith Kyle of The Nature Conservancy. ................................................................. 5

Figure 3. Grand Isle, Louisiana, experimental reef sites and reference sites......................................... 6

Figure 4. Lake Eloi, Louisiana, experimental reef sites and reference sites.......................................... 7

Figure 5. Lake Fortuna, Louisiana, experimental reef sites and reference sites. ..................................... 8

Figure 6. Reefsicles created for monitoring of bioengineered reefs.................................................. 14

Figure 7. Mean shoreline displacement for reference and reef treatments, both preconstruction and postconstruction, at Lake Eloi, Lake Fortuna, and Grand Isle, Louisiana. ........................................... 17

Figure 8. Change in soil volume behind the Grand Isle, Louisiana, reef as measured by using a TOPCON GTS-226 electronic total station and Surfer 8.03 to map the surface contours......................................... 18

Figure 9. Growth rate and cumulative mortality from 2011 and 2012 of experimental oysters located in cages adjacent to Grand Isle reef sites..................................................................................... 20

Figure 10. Overall mean salinity, total particulate matter, dissolved oxygen, and chlorophyll a for all Lake Eloi, Lake Fortuna, and Grand Isle sites................................................................................ 22

Figure 11. Gill net CPUE and species richness at Lake Eloi, Lake Fortuna, and Grand Isle

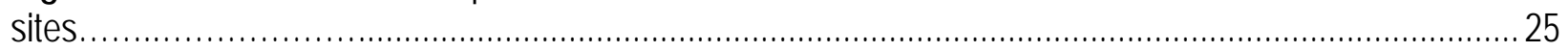

Figure 12. Cast net CPUE and species richness at Lake Eloi, Lake Fortuna, and Grand Isle sites......... 27

Figure 13. Seine CPUE and species richness at Lake Eloi, Lake Fortuna, and Grand Isle sites............. 29 


\section{Tables}

Table 1. Schedule of preconstruction data collected, construction dates, and postconstruction data collected in Louisiana.

Table 2. Range of environmental variables collected at each site, for all sample dates and treatments

Table 3. Gill net total species catch and mean catch per unit effort for each site in Louisiana...... 24

Table 4. Cast net total species catch and mean and standard error catch per unit effort for each Louisiana site 26

Table 5. Seine total species catch and mean catch per unit effort for each Louisiana site .28

Table 6. Grand Isle, Louisiana, tray data from 2011 and 2012 combined .30

Table 7. Lake Fortuna, Louisiana, tray data from 2012 


\section{Conversion Factors}

SI to Inch/Pound

\begin{tabular}{|c|c|c|}
\hline Multiply & By & To obtain \\
\hline \multicolumn{3}{|c|}{ Length } \\
\hline centimeter $(\mathrm{cm})$ & 0.3937 & inch (in.) \\
\hline millimeter $(\mathrm{mm})$ & 0.03937 & inch (in.) \\
\hline meter $(\mathrm{m})$ & 3.281 & foot $(\mathrm{ft})$ \\
\hline $\operatorname{meter}(\mathrm{m})$ & 1.094 & yard (yd) \\
\hline kilometer $(\mathrm{km})$ & 0.6214 & mile (mi) \\
\hline \multicolumn{3}{|c|}{ Area } \\
\hline square meter $\left(\mathrm{m}^{2}\right)$ & 0.0002471 & acre \\
\hline square meter $\left(\mathrm{m}^{2}\right)$ & 10.76 & square foot $\left(\mathrm{ft}^{2}\right)$ \\
\hline \multicolumn{3}{|c|}{ Volume } \\
\hline liter $(\mathrm{L})$ & 33.82 & ounce, fluid (fl. oz) \\
\hline liter $(\mathrm{L})$ & 2.113 & $\operatorname{pint}(\mathrm{pt})$ \\
\hline liter (L) & 1.057 & quart (qt) \\
\hline liter $(\mathrm{L})$ & 0.2642 & gallon (gal) \\
\hline cubic centimeter $\left(\mathrm{cm}^{3}\right)$ & 0.06102 & cubic inch $\left(\mathrm{in}^{3}\right)$ \\
\hline liter $(\mathrm{L})$ & 61.02 & cubic inch $\left(\mathrm{in}^{3}\right)$ \\
\hline \multicolumn{3}{|c|}{ Mass } \\
\hline $\operatorname{gram}(\mathrm{g})$ & 0.03527 & ounce, avoirdupois (oz) \\
\hline
\end{tabular}

Temperature in degrees Celsius $\left({ }^{\circ} \mathrm{C}\right)$ may be converted to degrees Fahrenheit $\left({ }^{\circ} \mathrm{F}\right)$ as follows:

${ }^{\circ} \mathrm{F}=\left(1.8 \mathrm{x}^{\circ} \mathrm{C}\right)+32$

Vertical coordinate information is referenced to the North American Vertical Datum of 1988 (NAVD 88).

Concentrations of chemical constituents in water are given either in milligrams per liter $(\mathrm{mg} / \mathrm{L})$ or in micrograms per liter $(\mu \mathrm{g} / \mathrm{L})$. 


\title{
Preliminary Assessment of Bioengineered Fringing Shoreline Reefs in Grand Isle and Breton Sound, Louisiana
}

\author{
By Megan K. La Peyre, ${ }^{1}$ Lindsay Schwarting, ${ }^{2}$ and Shea Miller ${ }^{2}$
}

\begin{abstract}
Restoration of three-dimensional shell habitats in coastal Louisiana presents a valuable and potentially self-sustaining approach to providing shoreline protection and critical nekton habitat and may contribute to water quality maintenance. The use of what has been called "living shorelines" is particularly promising because in addition to the hypothesized shoreline protection services, it is predicted that, if built and located in viable sites, these living shorelines may ultimately contribute to water quality maintenance through filtration of bivalves and may enhance nekton habitat. This approach, however, has not been tested extensively in different shallow water estuarine settings; understanding under what conditions a living shoreline must have to support a sustainable oyster population, and where these reefs may provide valuable shoreline protection, is key to ensuring that this approach provides an effective tool for coastal restoration.

This project gathered preliminary data on the sustainability and shoreline stabilization of three large bioengineered fringing reefs located in Grand Isle, Lake Eloi, and Lake Fortuna, Louisiana. We collected preconstruction and postconstruction physiochemical and biological data by using a before-after-control-impact approach to evaluate the effectiveness of these living shoreline structures on reducing marsh erosion, enabling reef sustainability, and providing other ecosystem benefits. Although this project was originally designed to compare reef performance and impacts across three different locations over 2 years, delays in construction because of the Deepwater Horizon oil spill resulted in reefs being built from 12 to 18 months later than anticipated. As a result, monitoring postconstruction was severely limited. One reef, Grand Isle, was completed in March 2011 and monitored up to 18 months postcreation, whereas Lake Eloi and Lake Fortuna reefs were not completed until January 2012, and only 8 months of postconstruction data are available. Data for the latter two sites thus reflect only the 2012 spring/summer seasons, which were further impacted by a direct hit by Hurricane Isaac in August 2012, which resulted in shoreward movement of approximately 14 percent of the bioengineered structures at Lake Fortuna. Given the shortened monitoring timeframe and significant differences in construction schedules, we were not able to provide a full postconstruction assessment of the sites or a full comparison of site success based on local site
\end{abstract}

\footnotetext{
${ }^{1}$ U.S. Geological Survey, Louisiana Cooperative Fish and Wildlife Research Unit, School of Renewable Natural Resources, Louisiana State University Agricultural Center, Baton Rouge, LA 70803.

${ }^{2}$ School of Renewable Natural Resources, Louisiana State University Agricultural Center, Baton Rouge, LA 70803.
} 
characteristics. Because many of the impacts that were identified for monitoring reflect longterm processes, results and data presented should be interpreted cautiously.

Sustainable oyster reefs require recruitment, growth, and survival at a rate that keeps pace with mortality and shell disarticulation. Although one site failed to recruit (establishment plus survival $>50$ millimeters $[\mathrm{mm}]$ ) over two spawning seasons, two sites only had 6 months postconstruction data available for assessment. Although there are good data on the requirements for oyster growth, there is limited explicit information on the site-specific water quality, hydrodynamic, and biological interaction effects that may determine successful reef establishment. Furthermore, interannual variability can significantly affect reef establishment, and our shortened timeframe of sampling (less than one spawning season for two of the reefs; two spawning seasons for one reef), combined with a lack of prerestoration monitoring data, limit our ability to draw any conclusions about long-term reef sustainability.

Bioengineered reefs are thought to provide some benefits to shoreline stabilization through their structure by immediately attenuating wave energies and directly reducing erosion rates at shorelines sheltered by the reefs but also by increasing sediment deposition behind the reefs. Preliminary data indicate differences in reef impact by site; given the short timeframe of postconstruction data at two of the sites, and differences in reef placement between sites, however, it is difficult to draw any conclusions. Longer-term data collection and further analyses comparing reef placement; local wind, wave energy, sediment transport processes; and local bathymetry may help in parameterizing sites where fringing reefs may be most beneficial for shoreline protection.

In addition to basic reef sustainability and shoreline stabilization, we measured both water quality parameters and nekton abundances around the newly created reefs and adjacent reference sites. Within the timeframe of monitoring, no effect of reefs on water quality was detected at any site. Given that water quality effects are hypothesized to result from the filtration activities of bivalves, and reefs either failed to recruit (settlement plus survival to $>50 \mathrm{~mm}$ ) or successfully recruited but only had a couple months of growth prior to this report, it was not expected that an effect would be detectable in this timeframe. Nekton such as blue crab, gulf menhaden, and anchovies were found to be more abundant on the reefs; larger, more transient species were not found to be affected by reef presence. Future work examining smaller organisms and juveniles, including more explicit studies examining why and how these organisms preferentially use oyster reefs, would be useful in the design of other bioengineered reefs and help in understanding the role of the reefs in supporting the nekton community.

It is clear from the initial work that ensuring correct site selection by better understanding what local site factors influence oyster populations is key to establishing successful living shoreline reefs. Ultimately, the success of the reefs in providing any ecosystem service relies on their ability to build a viable oyster population that is self-sustaining over the long term. As many of the ecosystem processes hypothesized to result from reefs develop over the long term (4-6 years), some level of monitoring over the next few years is highly recommended in order to accurately assess the long term viability of the reefs, their provision of ecosystem services, and to provide better guidance for future projects.

\section{Introduction}

Since the 1930s, coastal Louisiana has been losing wetlands in the Mississippi River Delta at a rate estimated to be as high as 64 square kilometers per year $\left(\mathrm{km}^{2} \mathrm{yr}^{-1}\right)$ (Barras and others, 2004). Much of this loss occurs in sheltered coastal areas, located within the extensive 
marsh complex. This marsh loss is occurring through a combination of processes including lack of riverine input, altered hydrology from canal construction, sea-level rise, and erosion. Because this marsh loss is widespread and located along the thousands of interior shorelines across Louisiana, numerous approaches are being examined to help reduce the loss. Within these same shallow-water areas, coastal Louisiana supports abundant oyster resources which thrive in midsalinity waters.

In recent decades, oysters have been termed "ecosystem engineers" because they alter the environment in which they live and provide a multitude of ecosystem services (Coen and others, 1999; Coen and others, 2007). As such, the use of oyster reefs to help sustain the coast by reducing shoreline erosion and enhancing fishery habitat has become a focus of recent management and restoration activities. Understanding not only what services oyster reefs may provide but also the conditions in which they can provide these services, along with the conditions in which sustainable reefs can be created, is critical to making them an integral part of coastal restoration.

Restoration and enhancement of coastal reefs are hypothesized to provide many benefits. When restored along eroding shoreline edges, these created or restored reefs have been called "living shorelines", which are hypothesized to provide a valuable and potentially self-sustaining approach to shoreline protection. The use of coastal reefs are also hypothesized to provide additional services including critical nekton habitat, enhanced recruitment for continued existence of shell reefs, and contributions to water quality maintenance (that is, Scyphers and others, 2011). These added values make this approach particularly desirable, and in recent years, numerous projects have been implemented to create living shorelines. Despite this proliferation of actual living shoreline creation projects, few data exist to guide project efforts with respect to site location or design, and many questions remain regarding the actual biological benefits of living shorelines, the effectiveness of living shorelines in reducing shoreline erosion, the longterm sustainability of living shorelines, and the identification of appropriate locations for successful living shoreline projects. This work presents preliminary data on the sustainability and ecosystem services developed at three living shoreline projects that were implemented between 2010 and 2011 in coastal Louisiana.

The Nature Conservancy, in collaboration with private landowners, State and Federal entities, and private contractors, led the creation of approximately $5.1 \mathrm{~km}$ of fringing shoreline structures in coastal Louisiana waters at three different eroding shorelines within shallow water areas (fig. 1). The initial artificial reef substrate provided for recruitment and reef development consisted of triangular units created with rebar, with mesh bags full of oyster shell placed within them (Reefblk ${ }^{\mathrm{TM}}$; fig. 2). These units were placed side by side, with each 1.5 meters (m) wide and $1 \mathrm{~m}$ high, and anchored approximately along the 1-m shoreline depth contour to create intertidal reefs with similar exposure regimes. The three project areas included Grand Isle, La. (1.4-km reef length; fig. 3), Lake Eloi, La. (2.4-km reef length; fig. 4), and Lake Fortuna, La. (1.3-km reef length; fig. 5). Reefs differed in length, based on landowner permissions, and all reefs had gaps located periodically along the reef which coincided with natural channels in the marsh. These three sites were chosen because they all are areas known to support oyster growth, and the expectation was that oysters would quickly recruit to the artificial reef structures. 


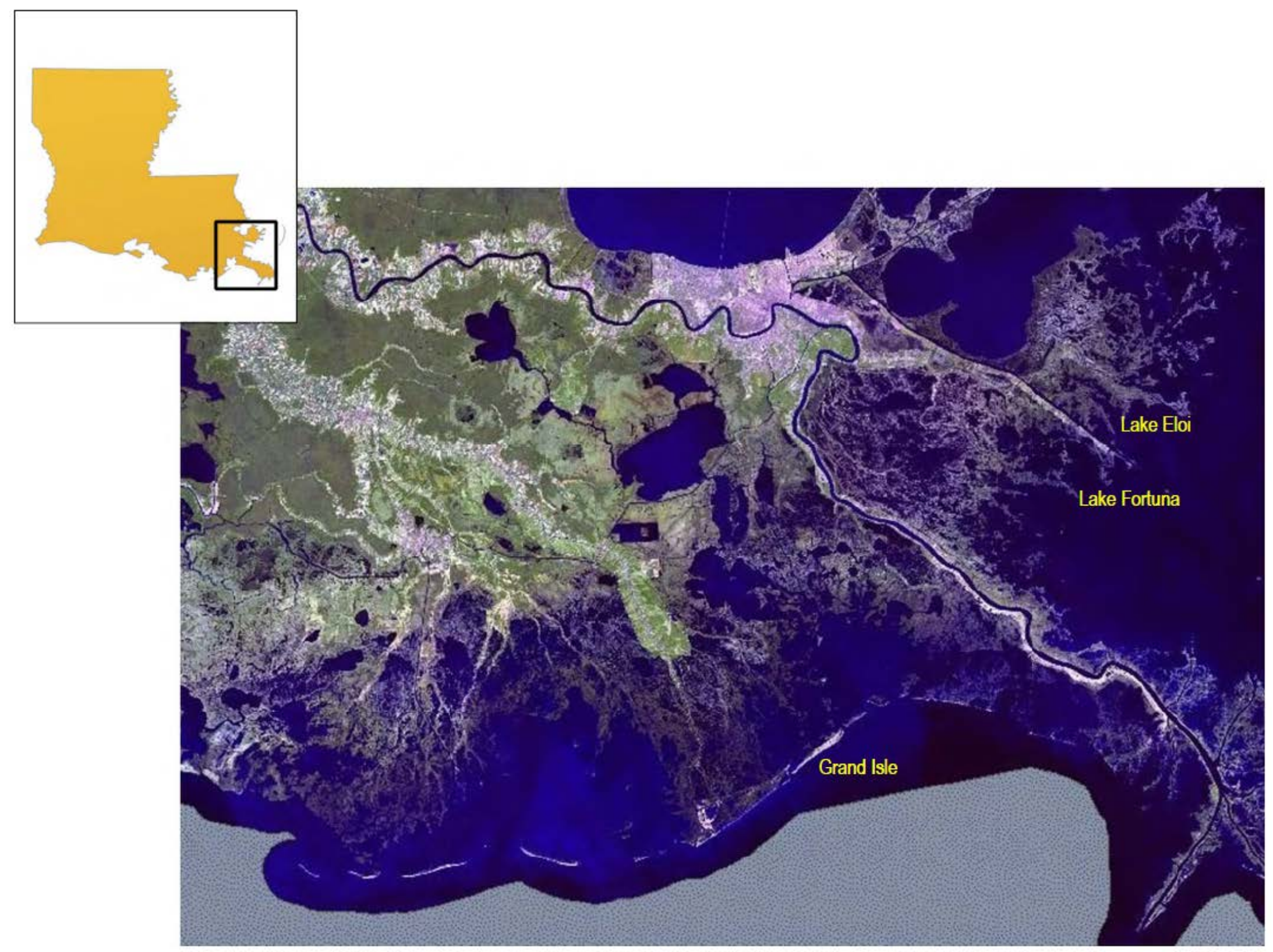

Figure 1. Map showing the location of three study sites where artificial reefs were built in coastal Louisiana. Grand Isle reef was completed in March 2011, and Lake Fortuna and Lake Eloi reefs were completed in December 2011 and January 2012, respectively. 


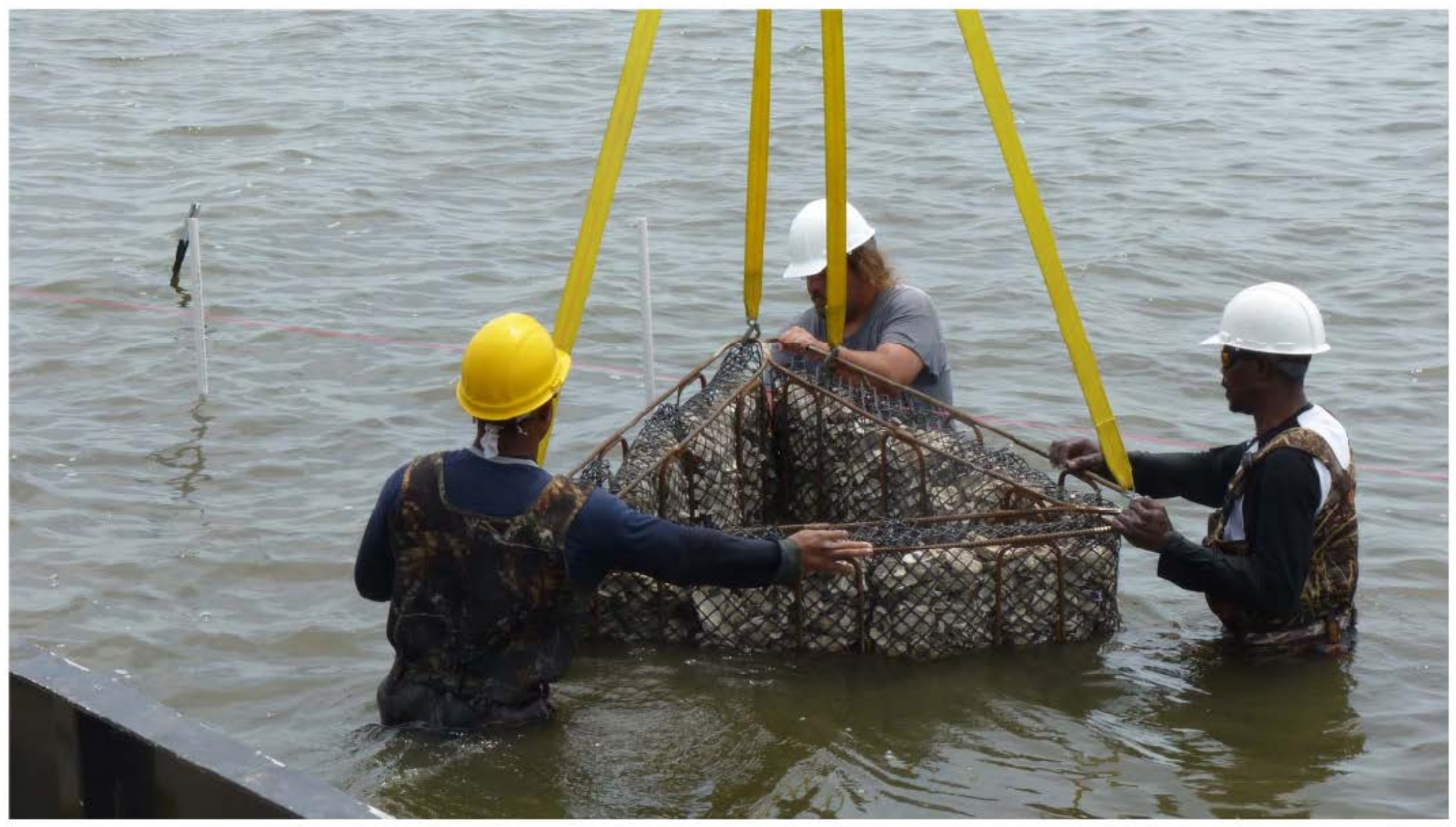

Figure 2. Photograph showing one triangular ReefB $/ k^{T M}$ unit being installed in coastal Louisiana waters. Photograph used with permission of Amy Smith Kyle of The Nature Conservancy. 


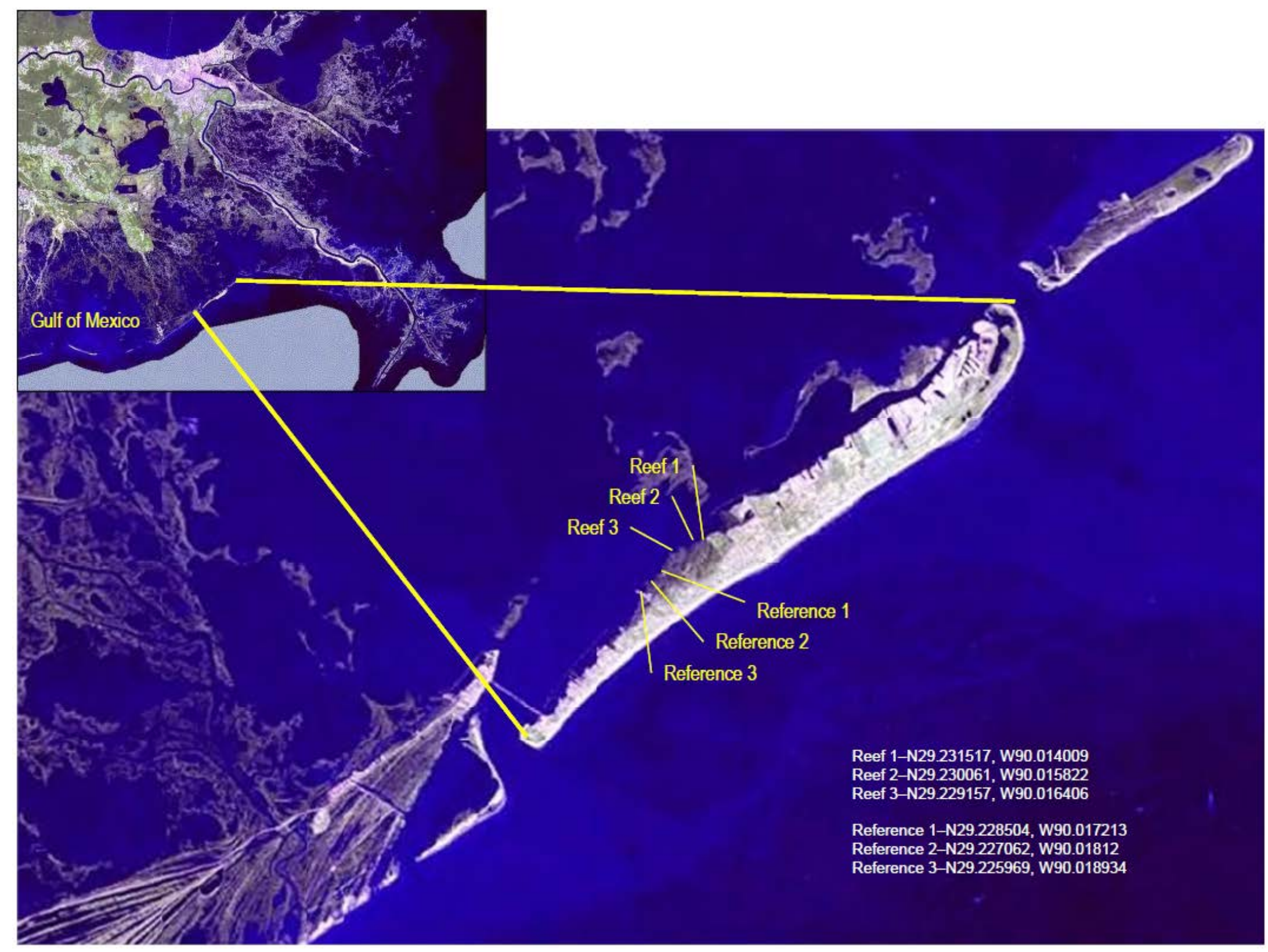

Figure 3. Map showing the Grand Isle, Louisiana, experimental reef sites and reference sites. 


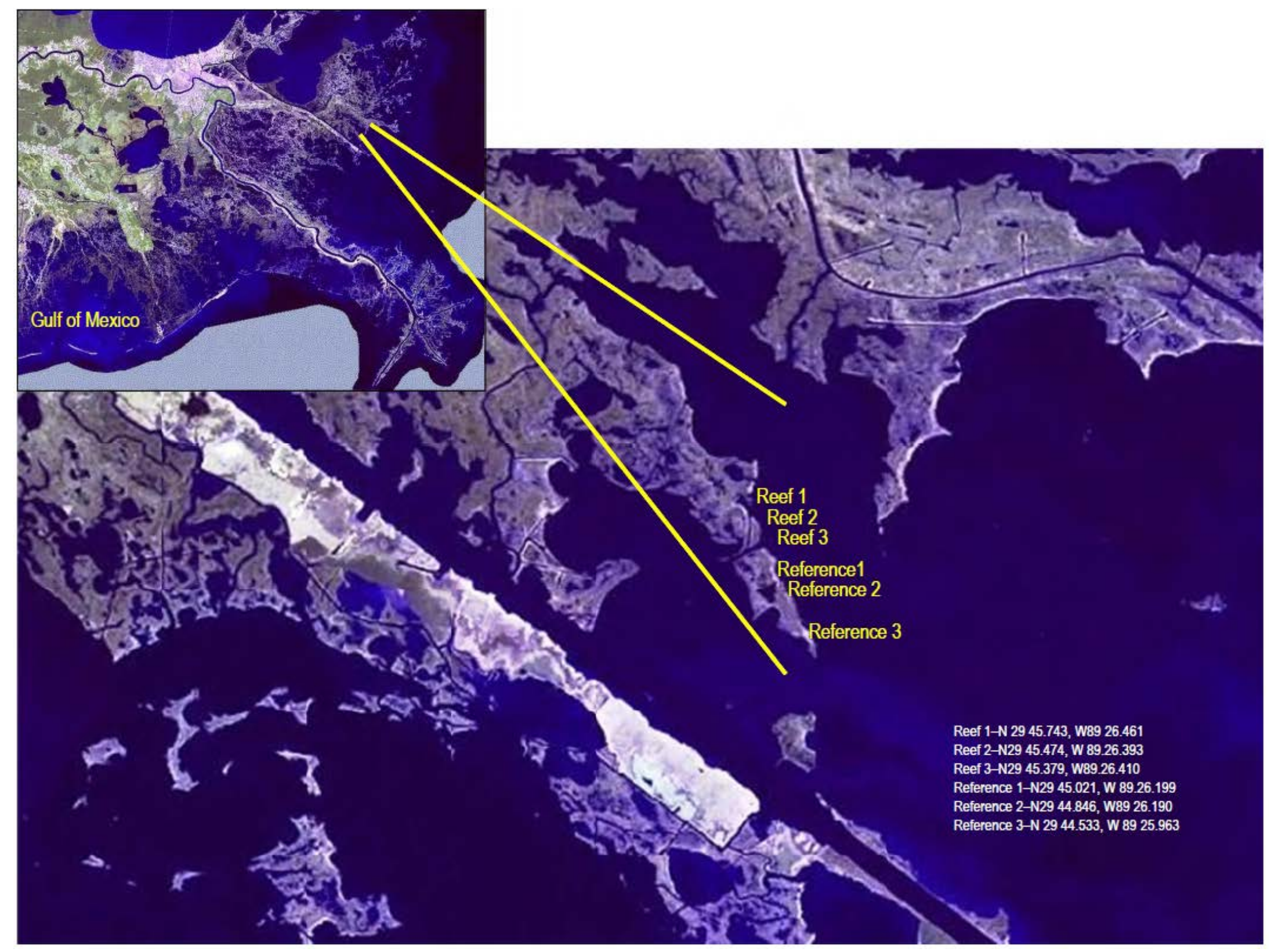

Figure 4. Map showing the Lake Eloi, Louisiana, experimental reef sites and reference sites. 


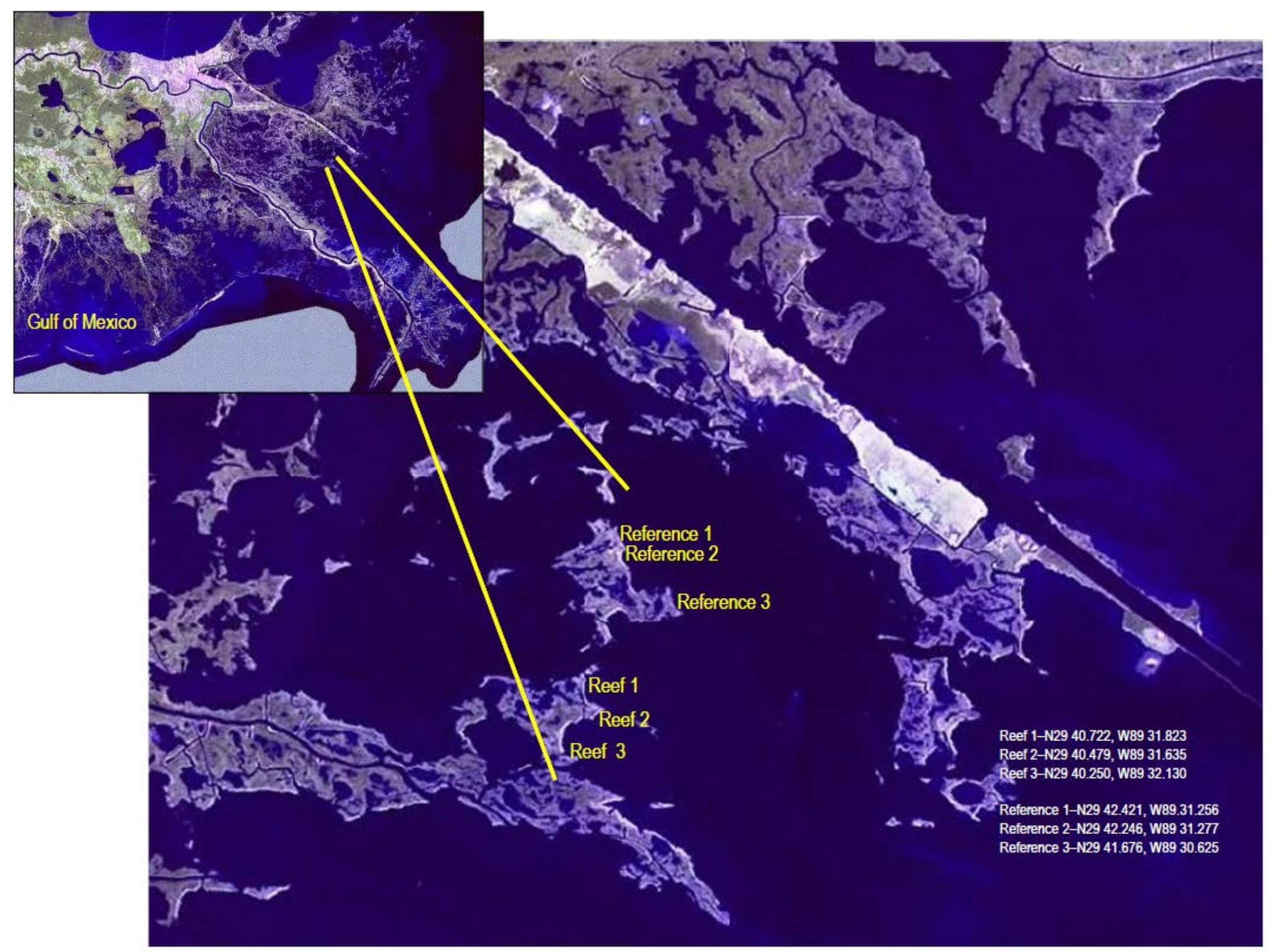

Figure 5. Map showing the Lake Fortuna, Louisiana, experimental reef sites and reference sites. 
The primary goal of this preliminary data collection was to measure the effectiveness of artificial reefs located adjacent to the shoreline in stabilizing the shoreline, supporting nekton, and quantifying their long-term sustainability. A secondary goal was to examine how location, measured by differences in water quality, may alter the effectiveness of the reefs in becoming sustainable or in providing any of the measured ecosystem services. Our specific objectives were to (1) quantify the effects of living shorelines on shoreline movement; (2) quantify the ability of these reef bases to be self-sustaining through natural oyster recruitment, survival, and growth; and (3) quantify added value of these living reefs in providing critical ecosystem services such as improved marsh vigor and enhanced nekton habitat. The unique aspect of this project was to compare the same reef design and treatments within three different environmental settings. For this comparison, we developed a quantitative reef monitoring plan, using a before-after-controlimpact design, which would allow us to differentiate between reef effects, site effects, and interannual variation effects. Preconstruction and postconstruction data collected included shoreline location, bathymetry, oyster recruitment and density, sediment organic matter and bulk density, emergent vegetation percent cover and biomass by species, nekton communities, and water quality (temperature, salinity, water clarity, chlorophyll $a$, total suspended solids) measurements.

We hypothesized that within the short term ( 2 years) following reef placement, the reefs would reduce wave energies and erosion rates behind the reefs. The reduction in energy behind the reefs would result in accumulation of sediment and a possible decrease of the adjacent marsh slope and would support a healthy emergent vegetation community. We also hypothesized that these reefs would recruit and provide suitable substrate for a viable oyster population. The development of a viable oyster population would result in reef sustainability but would also provide increased water filtration which would be measurable in water quality improvements. Lastly, we hypothesized that the creation of structure, and the creation of different habitats either within the structure or behind in lower energy areas, would provide for the support of increased nekton production by the reefs. We also hypothesized that micro-site characteristics in shoreline orientation and local water quality would alter the provision of these services and (or) alter the rate at which the reefs would come to provide these services.

\section{Study Area}

This project was conducted at three locations in coastal Louisiana: (1) Lake Eloi, (2) Lake Fortuna, and (3) Grand Isle (figure 1). These three locations are all within the shallow estuarine waters of coastal Louisiana and have highly eroding shorelines. Furthermore, these locations have historically supported good oyster growth. The Grand Isle reef is located on the north side of Grand Isle in Barataria Bay, La., and is immediately west of the Louisiana Sea Grant Oyster Hatchery. This shoreline runs predominantly east-west. Historical photos indicate significant loss of the back side of this barrier island. Lake Eloi and Lake Fortuna are located in Biloxi marsh, and are separated by the former shipping channel Mississippi River Gulf Outlet, which was closed in 2010 because of concerns that the channel allowed saltwater intrusion into freshwater areas. The Lake Eloi reef was placed along a shoreline which abuts current oyster lease and growing areas and is oriented predominantly north-south. Lake Fortuna reef was placed in a more exposed area of the marshes and is the most exposed of our three areas in terms of wave fetch and energy. The shoreline of the Lake Fortuna reef runs predominantly northsouth. 


\section{Reef Construction and Sampling Schedule}

The project was initiated in late 2009, with initial preconstruction monitoring occurring in February and March of 2010 (table 1). Because of the Deepwater Horizon oil spill in April 2010, which threatened to cover the sites with oil from the oil spill, all activities related to the project were put on hold prior to any construction activity, and access to sites was severely restricted through the summer of 2010 because of Federal and private clean-up activities.

In 2011, construction began, and the Grand Isle reef was completed in March 2011, Lake Fortuna in December 2011, and Lake Eloi in January 2012 (table 1). Because of the delays in construction, the 9-month spread of completion of reefs, and the required deadline of all activities to be reported by December 2012, sampling at all sites differed and was less than 1 full year at the Lake Fortuna and Lake Eloi reef sites and less than 2 years at Grand Isle. Because of differences in local bathymetry at each site, reefs at Lakes Eloi and Fortuna were placed significantly closer to the shoreline $(5-10 \mathrm{~m})$ as compared to the Grand Isle reef $(25-50 \mathrm{~m})$, thereby resulting in different reef set up and design. In August 2012, Hurricane Isaac passed immediately over reefs in Lakes Eloi and Fortuna, resulting in the displacement of approximately 14 percent of the reef units at Lake Fortuna. None of the displaced reefs occurred at sample stations.

Grand Isle data were collected immediately postconstruction (April 2011), and approximately bimonthly through the fall of 2012. Construction of the Lake Eloi and Lake Fortuna reefs was completed within 1month, and postconstruction data were collected immediately following reef construction in January 2012 and approximately bimonthly through fall 2012. Because 5 years of postinstallation data are generally recommended to fully assess the effectiveness of reef restoration, these data present only a very short-term view of the impact of the projects. 
Table 1. Schedule of preconstruction data collected, construction dates, and postconstruction data collected in Louisiana. Grand Isle was constructed in spring 2011; Lake Fortuna and Lake Eloi reefs were completed in December 2011 and January 2012, respectively. Summer 2010 was not sampled because of the Deepwater Horizon oil spill which prevented access to most coastal launch sites. Samples listed in bold are postconstruction samples; nonbold represent preconstruction samples. Spring, summer, and fall samples represent 1-2 sampling events.

[Spring, March-May; Summer, June-August; Fall, September-November; Winter, December-February; GI, Grand Isle; LE, Lake Eloi; LF, Lake Fortuna]

\begin{tabular}{|c|c|c|c|c|c|c|c|c|c|c|}
\hline & \multicolumn{3}{|c|}{2010} & \multicolumn{3}{|c|}{2011} & \multicolumn{4}{|c|}{2012} \\
\hline & Spring & Summer & Fall & Spring & Summer & Fall & Winter & Spring & Summer & Fall \\
\hline Shoreline & GI, LE, LF & - & $\mathrm{GI}$ & GI & GI, LE, LF & GI & LE, LF & GI & GI, LE, LF & GI, LE, LF \\
\hline Vegetation & GI, LE, LF & - & $\mathrm{GI}$ & GI & GI, LE, LF & GI & LE, LF & - & GI, LE, LF & - \\
\hline Soils & GI, LE, LF & - & $\mathrm{GI}$ & GI & GI, LE, LF & GI & LE, LF & - & GI, LE, LF & - \\
\hline Water quality & GI, LE, LF & - & $\mathrm{GI}$ & GI & GI, LE, LF & GI & LE, LF & GI, LE, LF & GI, LE, LF & - \\
\hline Nekton (transient) & GI, LE, LF & - & $\mathrm{GI}$ & GI & GI, LE, LF & GI & LE, LF & GI, LE, LF & GI, LE, LF & - \\
\hline Nekton (resident) & - & - & $\mathrm{GI}$ & GI & GI. LF & GI & LE. LF & GI, LE, LF & GI. LF & - \\
\hline $\begin{array}{r}\text { Oysters } \\
\text { O }\end{array}$ & - & - & - & $\mathrm{GI}$ & GI & GI & LE, LF & - & GI, LE, LF & GI, LE, LF \\
\hline
\end{tabular}




\section{Project Methods}

In February 2010, prior to reef construction, each location had a treatment area and a reference area identified. Within each of these areas, three sample points were randomly selected (3 areas [Grand Isle, Lake Eloi, Lake Fortuna] x 2 treatments [reference, shoreline] x 3 replicates $=18$ samples). The project was conceived to compare treatments across sites to examine both treatment and site effects. Because of unforeseen events of an oil spill, construction delays, and a hurricane, we were unable to do a full quantitative analyses and, in particular, site comparisons. Quantitative analyses presented within site, however, should still be interpreted cautiously; we justified quantitative analyses by site by assuming that replicate sample areas within each reef and reference area were of sufficient distance apart to represent independent samples. The extension of monitoring over a longer time period will enable more quantitative analyses of these data to explicitly compare both treatment and site effects. Preconstruction and postconstruction monitoring followed the same protocols which are detailed below.

\section{Shoreline Stabilization and Adjacent Marsh Vigor}

Shoreline stabilization was measured by following Meyer and others (1997) and Piazza and others (2005). At each sample point, five permanent base stakes were located in the marsh. A tape measure was used to determine the distance from the base stake to the marsh edge. Shoreline edge is defined as the farthest waterward extent of the wetland macrophytes. To ensure consistent measurements, shoreline edge was measured along a set compass heading.

To measure change in soil volume and shoreline slope change, one Grand Isle site and one Lake Fortuna site were selected for detailed transect surveys by using a TOPCON GTS-226 electronic total station. During preconstruction sampling (Grand Isle: September 2010; Lake Fortuna May 2011), five 35-m transects running from on the marsh perpendicular into the water were completed, recording elevation every 1-m along set compass points and resulting in more than 60 point measurements. At Grand Isle, postconstruction surveys were completed immediately postconstruction (April 2011) and in fall 2012 (October 2012). The Lake Fortuna site was only sampled postconstruction in fall 2012 (November 2012). Changes in shoreline slope and soil volume located behind the reef were calculated by using Surfer 8.03 Surface Mapping System (hereafter referred to as "Surfer"). Surfaces created from separate samplings were overlaid, and a change in sediment volume based on elevations was calculated through Surfer. Grand Isle preconstruction and postconstruction data are presented and compared. Lake Fortuna data are presented only for the provision of baseline data because of the short timeframe postconstruction.

Aboveground and belowground vegetation density and biomass and percentage of soil organic matter and bulk density were quantified in triplicate at each sample point. At each sample point, triplicate quarter meter quadrats were haphazardly thrown to land within $1 \mathrm{~m}$ of the shoreline edge. Percent vegetative cover by species was recorded. All aboveground biomass was removed, returned to the lab at Louisiana State University (LSU) AgCenter, Baton Rouge, La., and quantified in the laboratory by drying to a constant biomass (gram (g) dry weight), and recording biomass by species. Within each quadrat, duplicate $5 \times 15$ centimeter $(\mathrm{cm})$ cores were collected. One core was used to quantify belowground vegetative biomass by rinsing all sediment by using a 3-mm sieve and by drying vegetative material to a constant biomass (g dry weight). The second core was used to determine percentage of soil organic matter by using loss 
on ignition in a muffle furnace. Bulk density was also calculated from these cores prior to firing in the muffle furnace. Bulk density is calculated as gram per cubic centimeter.

\section{Reef Sustainability}

Reef sustainability was monitored by collecting data for on-reef recruitment and oyster growth and mortality. This measure of sustainability was to determine if over time, and with the degradation of reef construction materials, a thriving oyster population would establish and maintain structure. Reef durability, such as longevity of the artificial reef base material and the ability of the reef structure to stay in position, were not included as goals in this project. Oysterpopulation distribution was monitored by estimating the number and size of oysters located over a 0.25 square meter $\left(\mathrm{m}^{2}\right)$ quadrat area on the reef. Initial plans called for removal of shell from bags for volumetric sampling. At two of the sites, removal of shell proved difficult within months of site establishment because of the presence of fouling organisms immediately after reef construction, and thus estimation by using visual and tactile clues was used because of the submerged nature of the reefs.

Because of difficulties encountered in sampling from the created reefs in turbid waters, we established minireef prototypes (reefsicles) at the Grand Isle site which consisted of minibags of oyster shell placed $0.5 \mathrm{~m}$ off-bottom (fig. 6). These reefsicles allowed us to track oyster recruitment and growth by removing the reefsicles from the water to count and measure oysters. Nine reefsicles were placed adjacent to the Grand Isle reef in April 2011; of these 9 reefsicles, 3 were covered in predator exclusion cages in order to account for differences in oyster populations which may be attributed to predation mortality. Because of the delayed construction of the Lake Eloi and Lake Fortuna reefs, logistics, and uncertainty in monitoring activities beyond several months postconstruction, reefsicles were not established at these sites. At Grand Isle, reefsicles were sampled in October 2011 and again in October 2012, and density of live and dead oysters recorded. 


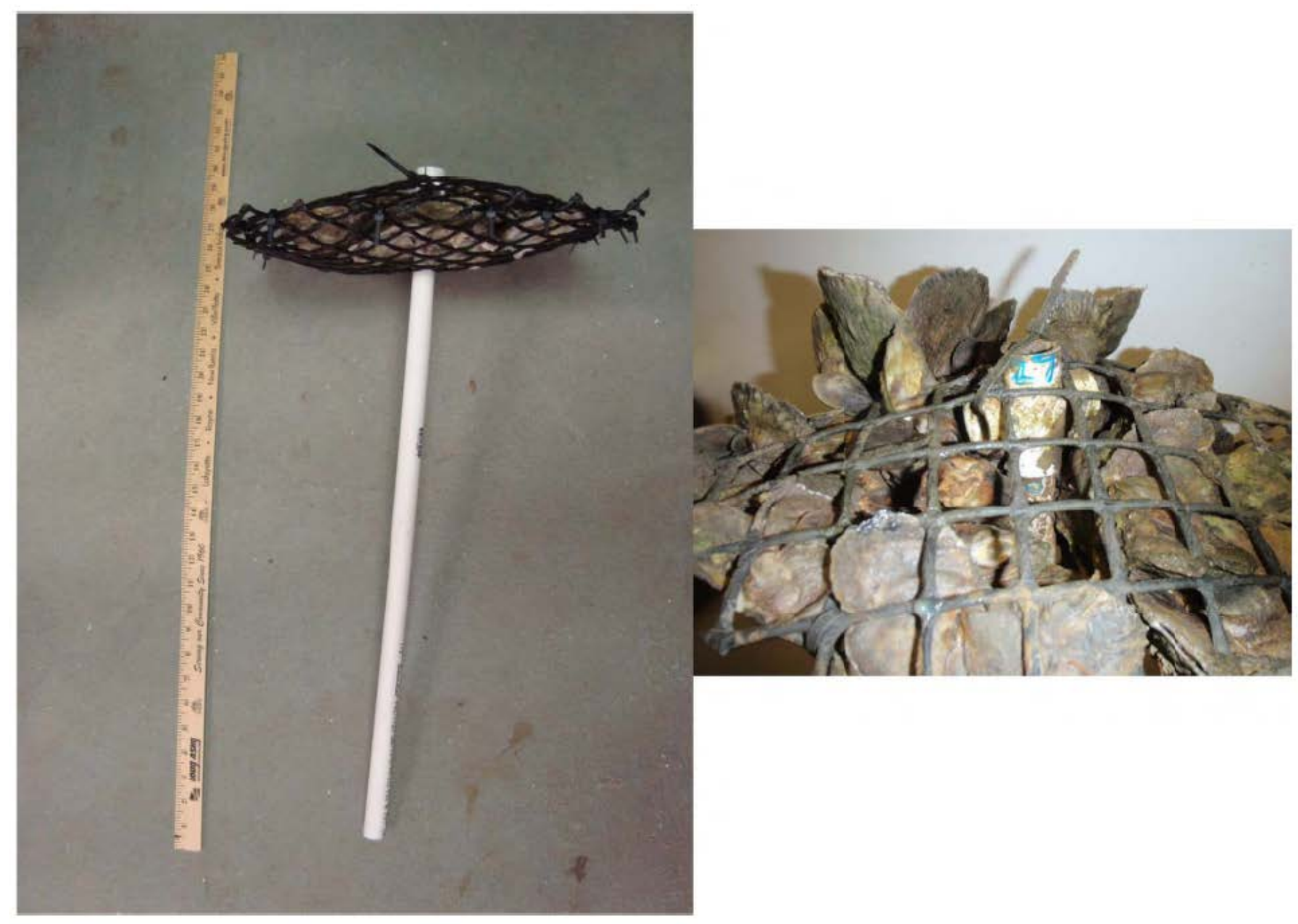

Figure 6. Photographs showing the reefsicles created for monitoring of bioengineered reefs. Miniportions of the bioengineered reef material is epoxied to a PVC pole and placed in the sediment adjacent to the created reef so that reef material is held 30 centimeters (cm) off-bottom. Reefsicles are sampled with replacement prespawning and postspawning periods. To examine mortality from predation, predator exclusion cages were designed to fit over the reefsicles. 
At Grand Isle, data were also collected for off-reef recruitment and oyster growth and mortality by using caged oysters. To better understand the dynamics of reef sustainability, oyster growth, mortality, condition, and Perkinsus marinus (Dermo) infection, intensities were measured in experimental bags placed adjacent to the reefs. In 2011, two bags of $1002.5-\mathrm{cm}$ oysters spawned at the LSU Sea Grant Oyster Hatchery were placed adjacent to the reef. In 2012, four bags of 100 2.5-cm oysters spawned at the LSU Sea Grant Oyster Hatchery were placed adjacent to the reef. Size and mortality were measured bimonthly, and disease prevalence and condition of 15 oysters were measured bimonthly. Cumulative mortality was calculated for each year, and growth rates were calculated by using shell length $\left(\mathrm{GR}=\left[\mathrm{SL}_{\mathrm{t}}-\mathrm{SL}_{\mathrm{t}-1}\right] /[\#\right.$ days*30]), where $\mathrm{GR}=$ growth rate; $\mathrm{SL}=$ shell length; and $\mathrm{t}=$ time. Growth rates were standardized to a 30day month. These data are valuable in explaining on-reef observations of oyster population dynamics.

\section{Water Quality}

Temperature (degrees Celsius $\left[{ }^{\circ} \mathrm{C}\right]$ ), salinity, and dissolved oxygen (milligrams per liter $\left[\mathrm{mg} \mathrm{L}^{-1}\right]$ ) were measured every field visit by using a YSI model 556 water quality meter (Yellow Springs Instruments, Ohio) at each sample point. Water clarity was measured by using a secchi disk (centimeters). Furthermore, two opaque bottles of water were collected at $0.5 \mathrm{~m}$ below the surface, immediately adjacent to the reef; placed on ice; and taken back to the lab to process for total organic matter, total inorganic matter $\left(\mathrm{mg} \mathrm{L}^{-1}\right)$, and chlorophyll $a$ (micrograms per liter $[\mu \mathrm{g}$ $\left.\mathrm{L}^{-1}\right]$ ). Ideally, the goal over the long term is to compare oyster population development within these different sites with differing water quality variables and to compare differences in water quality impacts of oyster reefs between the sites. Further monitoring will hopefully accomplish this comparison over the next few years.

\section{Habitat Enhancement}

Nekton recruitment and use of the constructed structures was measured by sampling the nekton community with four different gear types. Gill nets were used to capture the large, transient fish community. The 11-m experimental gill nets consist of 4 panels, each $2.7 \times 1.8 \mathrm{~m}$ and with mesh sizes $3.8,5.1,6.4$, and $7.6 \mathrm{~cm}$. The gill nets were placed perpendicular to the reefs, on the seaward side of the reefs, and soaked for 1 hour. All gill net samples were processed in the field by recording species identity and by taking total length and biomass. Time of day and water quality measurements were taken with each sample.

To characterize the juvenile and resident communities, five 2.4-m diameter cast net (3 $\mathrm{mm}$ mesh) samples were taken at each sample point in the area between the reef and the marsh vegetation. Furthermore, two 10-m seine pulls by using a $3-\mathrm{m}$ bag seine ( $3 \mathrm{~mm}$ mesh) near the marsh edge and near the reef structure, on the marsh side, were collected. All cast net and seine samples were bagged, placed on ice, and returned to the lab for further processing.

At Grand Isle and Lake Fortuna, resident communities were examined postconstruction by deploying substrate trays filled with oyster shell in August 2011 and 2012 and allowed to sit for 3 weeks before collection of all trays. Because of the impracticality of using nets to capture the cryptic species that live within the complex oyster reef matrix, trays were used to characterize the smaller fish and invertebrate communities that are known to reside in and frequent healthy reefs (Lehnert and Allen, 2002; Plunket and La Peyre 2005; Yeager and Layman, 2011). Each tray $\left(0.22 \mathrm{~m}^{2}\right)$ was modified by attaching a drawstring bag net with fine mesh $\left(2.6 \mathrm{~mm}^{2}\right)$. The sides of this net are gathered at the base of the tray while it is deployed, 
and prior to retrieval, the net is drawn tight to enclose the tray contents, thereby preventing the escape of more mobile organisms (Beck, 2011). All organisms were placed in sample bags and put on ice for transport to the laboratory at LSU, where they were processed and species identification and total length and weight were recorded. Density of organisms were calculated, and the community was described.

All gear types were analyzed separately. Because of differences in construction schedules, and resulting sampling, all sites were described and analyzed separately. Catch per unit effort (CPUE) was standardized by hour soak time (gill net), cast net throw, 10-m seine pull, or per square meter (trays). Species richness was calculated as the average total number of species caught per treatment type over all sampling events. Data were analyzed with CPUE and species richness as the independent variables and with treatment and construction status as the independent variables within each site. Future analyses would compare reefs by sites by using more complex statistics. Individual species comparisons between postconstruction reef and reference sites were performed with a students t-test.

\section{Results and Discussion}

\section{Shoreline Stabilization}

Shoreline retreat averaged $13.7 \pm 1.7 \mathrm{~cm} \mathrm{mo}^{-1}$ across all three sites, treatments, and construction status (figure 7). Lake Fortuna had reduced erosion rates at reef sites postconstruction, thereby gaining shoreline at an average rate of $0.4 \pm 5.8 \mathrm{~cm} \mathrm{mo}^{-1}$. Lake Eloi had reduced postconstruction erosion rates at the reef site in comparison to the reference site, indicating that the reef may be having a positive effect; preconstruction erosion rates at both sites, however, were lower than all postconstruction data. Given the short timeframe of sampling, these results should all be interpreted with caution because shoreline erosion is known to be highly temporally variable and may depend on local storm and wind patterns. 


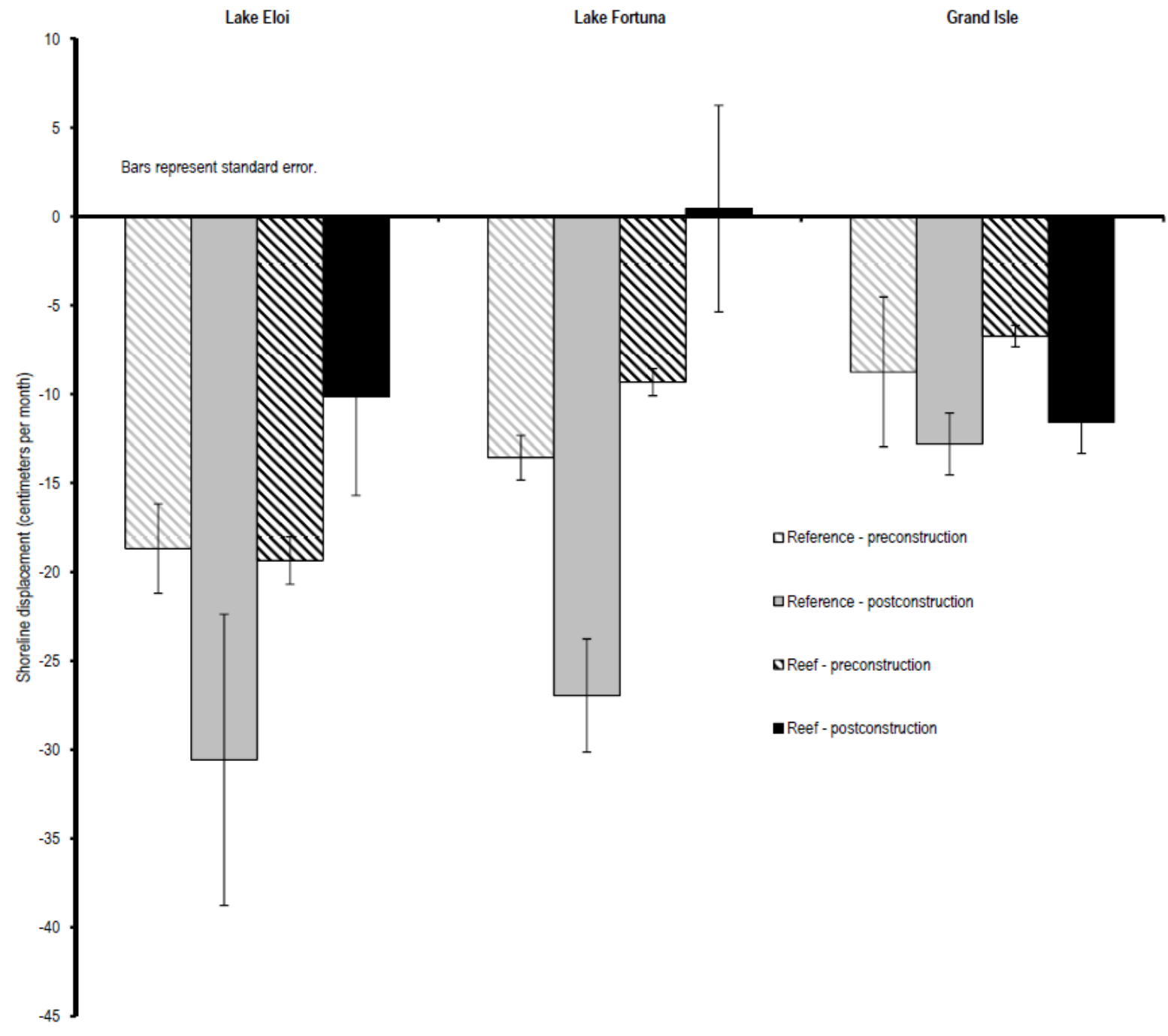

Figure 7. Graphs showing the mean shoreline displacement (centimeters per month) for reference and reef treatments, both preconstruction and postconstruction, at Lake Eloi, Lake Fortuna, and Grand Isle, Louisiana. Negative values indicate shoreline retreat. Preconstruction data for Lake Eloi and Lake Fortuna represent the mean change for the period February 18, 2012 through August 11, 2011. Postconstruction data for Lake Eloi and Lake Fortuna represent the mean change for the period January 31, 2012-July 24, 2012. Grand Isle preconstruction is February 2, 2012September 9, 2010; postconstruction is April 7, 2011-June 28, 2012. Periods during construction are not included in the analyses but, given the short timeframe of sampling, may be reflected in postconstruction shoreline change. 
Grand Isle marsh erosion showed no impact of reef construction on shoreline location over the 18 months of monitoring, with shoreline erosion retreat at reef sites at $6.7 \pm 0.6 \mathrm{~cm} \mathrm{mo}^{-1}$ prior to reef construction and $11.6 \pm 1.8 \mathrm{~cm} \mathrm{mo}^{-1}$ following reef construction. Surveys of the site, as well as personal observations, however, do indicate some accumulation of soft sediments behind the reefs, thus making it difficult to move around. This observation is supported by the bathymetry survey that was conducted at Grand Isle which measured an increase in soil volume in the range of $4-6 \mathrm{~cm} \mathrm{mo}^{-1}$ at the reef site only (figure 8).

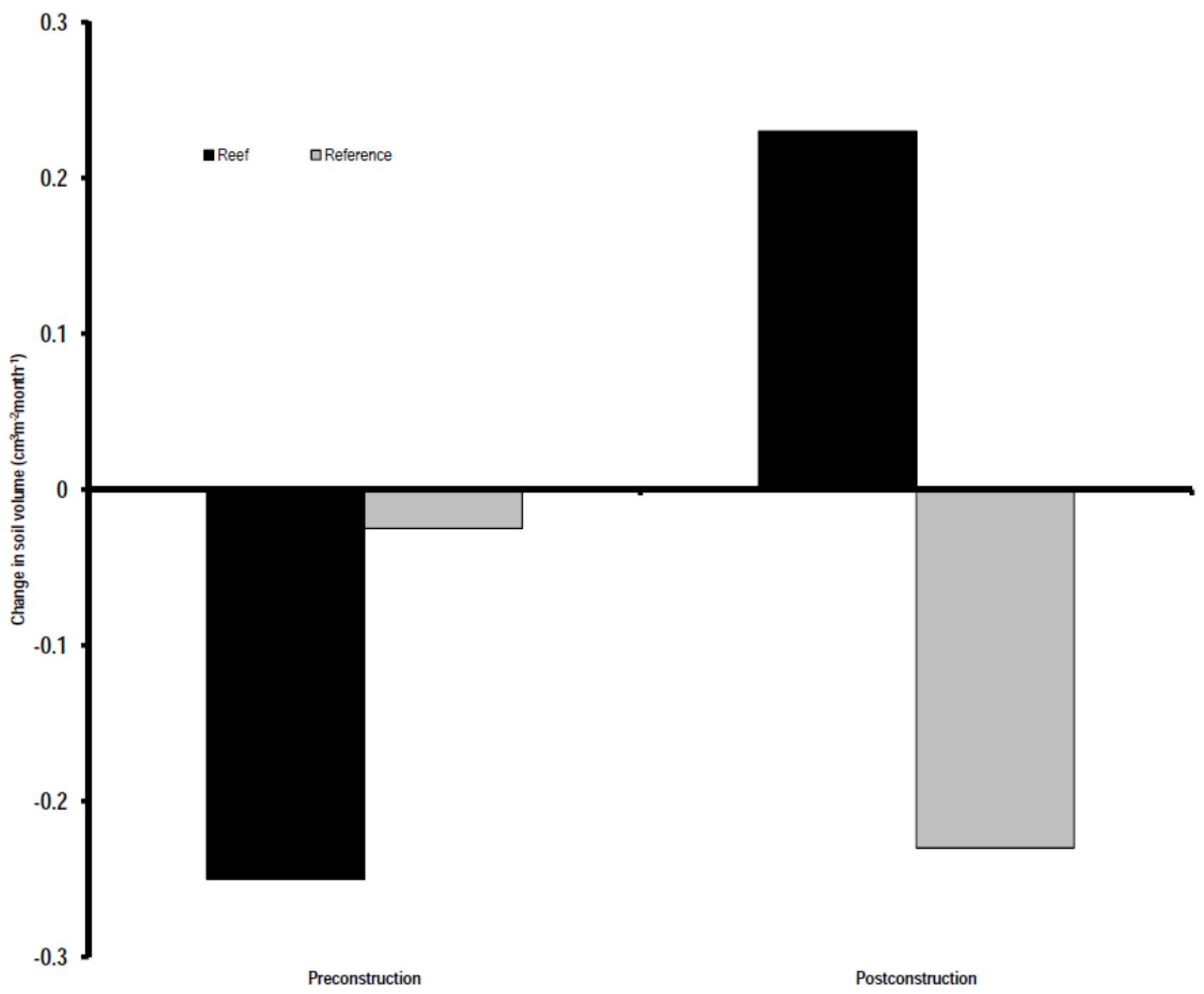

Figure 8. Graph showing the change in soil volume behind the Grand Isle, Louisiana, reef as measured by using a TOPCON GTS-226 electronic total station and Surfer 8.03 to map the surface contours. Positive numbers indicate an increase in sediment; negative numbers indicate a loss in sediment. Results do not account for site subsidence or effects of reef construction on changes in bathymetry. Preconstruction is for the period from September 20, 2010-April 7, 2011; postconstruction is for the period April 7, 2011October 19, 2012. 
Direct impacts from construction could not be separated from the preconstruction data. Although sites are not directly comparable at this time given the different timeframes of sampling, the construction of Grand Isle reefs farther from the shoreline as compared to Lake Eloi and Lake Fortuna sites (30-50 versus 5-10 m) may explain the difference in shoreline reduction observed behind the different reefs. Better understanding of the relationship between shore bathymetry, reef location and wave energy directly behind the reefs would provide valuable insight into the actual effect of the reefs on wave attenuation.

Percentage of organic matter and soil bulk density were significantly correlated $(\mathrm{p}<$ 0.0001 ), thus only percent organic matter is presented. The BACI analyses by site indicated there was no reef construction effect evident on soil percent organic matter.

Vegetative species found at the sites were typical brackish salt marsh species including Spartina alterniflora, Distichlis spicata, Juncus roemerianus, Spartina patens, Distichlis spicata, Salicornia virginica, and Avicennia germinans. Dominant species at Grand Isle sites were Spartina alterniflora, at both reef and reference sites, and Batis maritima, which was only present at reef sites. Percentage of cover varied between 40 and 60 percent at all Grand Isle sites. There was no difference in mean aboveground vegetation biomass between treatments or construction status (overall mean $1468.4 \pm 124.4$ grams per square meter $\left[\mathrm{g} \mathrm{m}^{-2}\right]$ ).

Lake Eloi and Lake Fortuna reefs showed a significant difference between preconstruction and postconstruction total percentage of cover at both reef and reference sites. Because the only postconstruction monitoring occurred only 6 months postconstruction, these data should be interpreted with caution because they may reflect seasonal variation, construction impacts, or larger scale regional patterns. Dominant species were Spartina alterniflora at Lake Eloi sites and Distichlis spicata at Lake Fortuna sites.

\section{Reef Sustainability}

Both Lake Eloi and Lake Fortuna sites had oyster recruitment, which was measured in August 2012. Densities of oysters 6 months postconstruction were $10.7 \pm 6.8$ individuals per

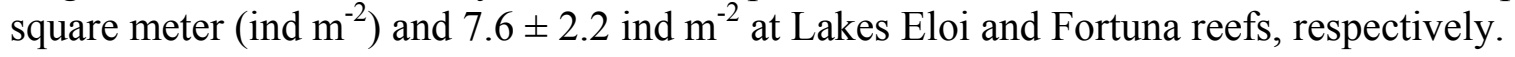
Although these numbers are low, they reflect only the first season and likely only one spawning event. In this region, oysters generally spawn for the first time in April/May and then may have 2 or 3 more spawning events before the weather cools in November (Supan and Wilson, 2001).

No on-reef recruitment (attachment plus survival to $>50 \mathrm{~mm}$ size) has been recorded to date at Grand Isle. There was evidence of spat settlement based on scars from attached larvae, but no surviving spat or larger oysters were recorded on the reefs or the experimental reefsicles. There was limited recruitment of barnacles and mussels noted, but high algae in both summers $(2011,2012)$ may also have severely limited all settlement. Although the salinity in the Grand Isle area is known to support high oyster growth, the area also supports a significant oyster drill population, and predation from blue crab on small oysters and drum on larger oysters has been investigated in a number of projects in this area. Lack of development of a thriving oyster reef may be because of a combination of factors including high predation and high algae coverage on the reef structures each spring prior to oyster spawning.

In 2011 and 2012, caged oysters at Grand Isle had good growth (mean $>2 \mathrm{~mm} \mathrm{mo}^{-1}$ ), and mortality was below 50 percent (fig. 9). Overall condition index declined as expected, from 10.0 $( \pm 1.9)$ at their initial deployment in December 2011 to $2.6( \pm 0.6)$ in September 2012, because of normal spawning and summer stresses. Although infection prevalence by $P$. marinus (Dermo) ranged from a low of 30 percent to a high of 93 percent, mean overall infection level of oysters at 
Grand Isle remained in the low to moderate range throughout the experiment $(13,644 \pm 6,456$ spores $\mathrm{g}^{-1}$ ) and likely did not contribute to oyster mortality.

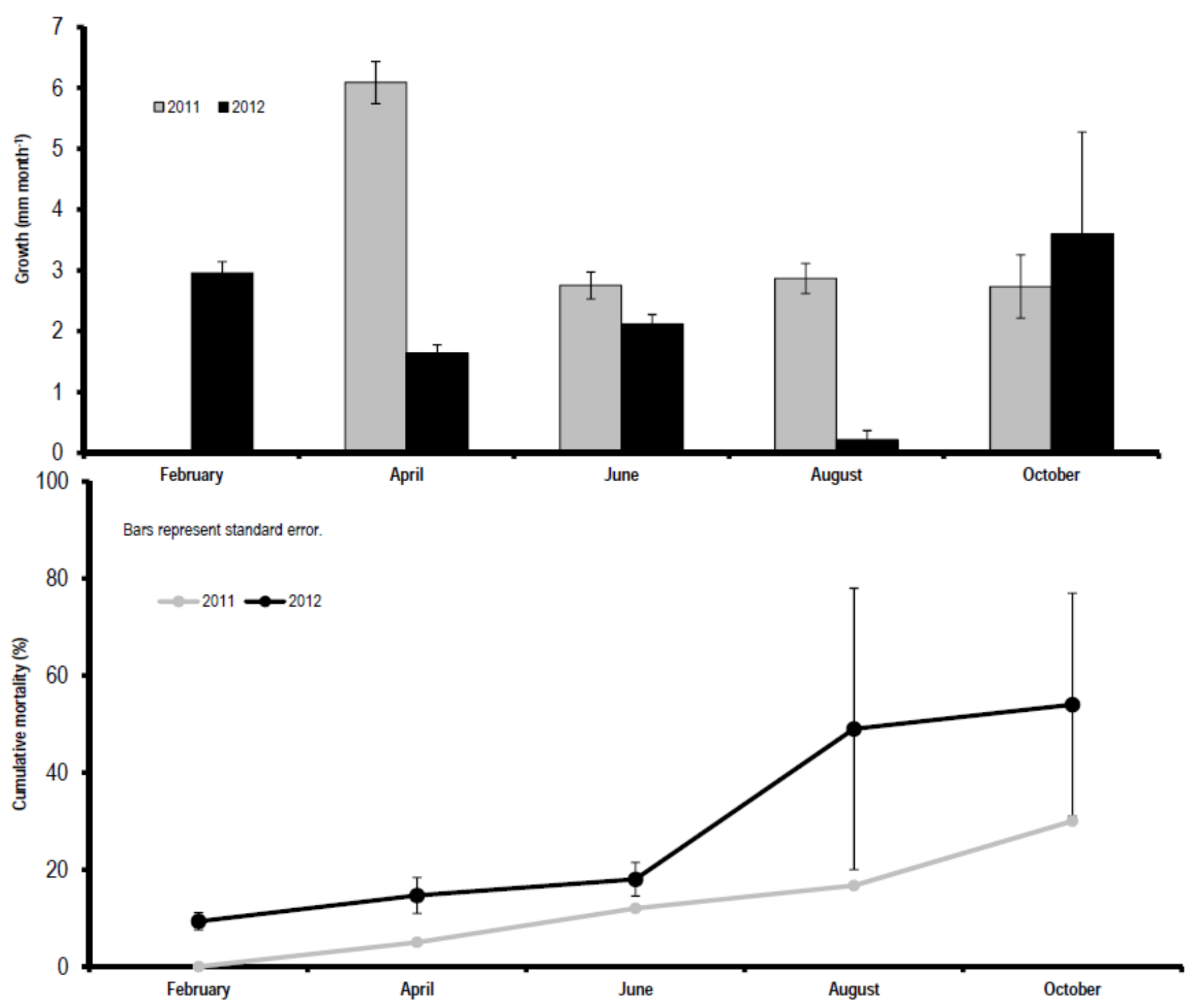

Figure 9. Graphs showing the growth rate (mean SE mm mo-1) and cumulative mortality (\%) from 2011 and 2012 of experimental oysters located in cages adjacent to Grand Isle reef sites.

The data from 2 years of caged oyster experiments indicate that this area does support good adult oyster growth $(>2.5 \mathrm{~cm})$ when oysters are protected from predation. It is still unclear, however, how these adult oysters would do outside the confines of the cage when subjected to predation. Further work comparing mortality and growth in caged and open cage adult oysters would be useful in determining if this reef would support a viable adult population. That said, the lack of recruitment (settlement plus survival) on the Grand Isle reefs may present a barrier to establishment of a viable oyster population. Further studies that examine whether adult oysters 
protected from predation could survive and spawn on the reef may be useful in determining whether this site remains a viable area for further restoration. Furthermore, the question of whether the establishment of an adult population provides increased structural complexity that may better protect new recruits and allow spat to survive and grow to larger oysters needs to be explored.

\section{Water Quality}

At each site, water-quality variables (salinity, temperature, water clarity, dissolved oxygen, total particulate matter, chlorophyll $a$ ) varied as expected, that is, by season and year but not by treatment or construction status (table 2, fig. 10). As planned in the original project design, there were differences between sites with higher salinity at Grand Isle (21.7 \pm 0.7$)$ and sites with lower salinity at Lake Eloi (16.5 \pm 1.0$)$ and Lake Fortuna (13.0 \pm 0.3$)$, and some differences in chlorophyll $a$, total particulate matter, and water clarity among sites. With more data and time from construction ( $>8$ months), it will be extremely valuable to compare how the oyster reefs sustain themselves within the different water quality environments and how the impacts on water quality differ among the sites with these differing characteristics.

Table 2. Range (minimum and maximum) of environmental variables collected at each site, for all sample dates and treatments.

[Temp, temperature in degrees Celsius; DO, dissolved oxygen in milligrams per liter; clarity, Secchi depth in centimeters; TPM, total particulate matter in milligrams per liter; Chl. a, chlorophyll a in micrograms per liter]

\begin{tabular}{|r|c|c|c|}
\hline & Lake Eloi & Lake Fortuna & Grand Isle \\
\cline { 2 - 4 } Temp $\left({ }^{\circ} \mathrm{C}\right)$ & $16.4-33.1$ & $12.9-34.7$ & $13.0-34.4$ \\
Salinity & $8.3-20.5$ & $10.5-15.7$ & $14.3-27.7$ \\
DO $\left(\mathrm{mg} \mathrm{L}^{-1}\right)$ & $4.4-8.8$ & $0.4-8.4$ & $3.8-12.2$ \\
Clarity $(\mathrm{cm})$ & $32.5-91.0$ & $16.0-68.0$ & $23.0-76.0$ \\
TPM $\left(\mathrm{mg} \mathrm{L}^{-1}\right)$ & $6.0-104.0$ & $5.3-84.7$ & $3.3-142.7$ \\
Chl. $a\left(\mu \mathrm{g} \mathrm{L}^{-1}\right)$ & $5.5-115.6$ & $3.6-36.3$ & $1.3-182.9$ \\
\hline
\end{tabular}



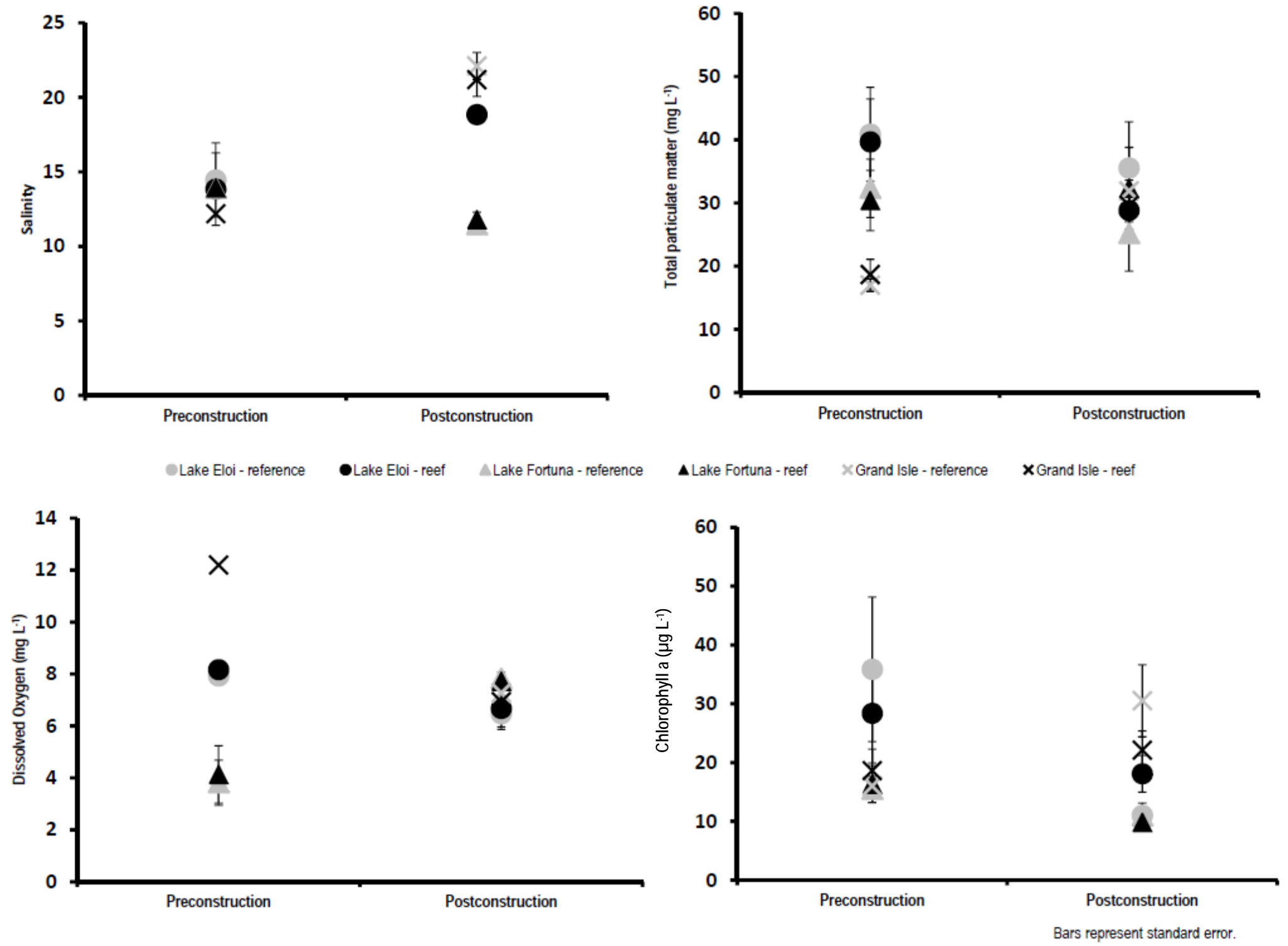

Figure 10. Graphs showing the overall mean salinity, total particulate matter $\left(\mathrm{mg} \mathrm{L}^{-1}\right)$, dissolved oxygen ( $\left.\mathrm{mg} \mathrm{L}^{-1}\right)$, and chlorophyll a $\left(\mu \mathrm{g} \mathrm{L}^{-1}\right)$ for all Lake Eloi, Lake Fortuna, and Grand Isle sites. 


\section{Habitat Enhancement}

All sites had two preconstruction sampling events for nekton. Grand Isle had five postconstruction sampling events, whereas Lake Eloi and Lake Fortuna had two postconstruction sampling events. Overall, in gillnet, cast net, and seine and substrate trays, 10,052 individuals were captured, consisting of 66 species of fish and invertebrate nekton.

Gill nets were deployed in triplicate at each reef and reference site for each sampling event. In total, 278 individuals were collected across all mesh sizes, consisting of 19 species of fish and invertebrates (table 3). The most abundant organisms were bull shark (Carcharhinus leucas), accounting for 36.7 percent of the overall catch, and hardhead catfish (Ariopsis felis), which accounted for 22.7 percent of the overall catch. Other abundant organisms included blue crab (Callinectes sapidus), accounting for 7.9 percent of the overall catch; gulf menhaden (Brevoortia patronus), 5.8 percent; and gaftopsail catfish (Bagre marinus), 4.7 percent. These five most abundant species accounted for 77.7 percent of the overall catch by gill nets. Commercially and recreationally important species including spotted seatrout (Cynoscion nebulosus), gulf menhaden, and red drum (Sciaenops ocellatus) were captured. Postconstruction data found similar adult fish abundances between sites and treatments, and no statistical differences were identified within site by treatment for overall abundance or for dominant species abundance (student's t-test; $\mathrm{p}>0.05$ for all tests; fig. 11). 
Table 3. Gill net total species catch and mean (standard error) catch per unit effort (CPUE) for each site in Louisiana. Sample periods of prereference, postreference, prereef, and postreef are not equivalent among sites. Lakes Eloi and Fortuna preconstruction data represent combined spring 2010 and summer 2011 samples; postconstruction samples represent winter, spring, and summer 2012 samples. Grand Isle preconstruction data represent combined spring and fall 2010 samples; postconstruction data represent combined spring and summer 2011 and 2012 samples. Data are presented only for baseline data information.

[N=105 1-hour gill net sets; 11 sampling events; total captured = 278 organisms; period (.), "0" catch; Preref., Preconstruction reference sites; Postref., Postconstruction reference sites; Prereef, Preconstruction reef sites; Postreef, postconstruction reef sites]

\begin{tabular}{|c|c|c|c|c|c|c|c|c|c|c|c|c|c|c|}
\hline \multirow[b]{2}{*}{ Species } & \multirow[b]{2}{*}{ Common name } & \multirow[b]{2}{*}{ Total } & \multicolumn{4}{|c|}{ Lake Eloi } & \multicolumn{4}{|c|}{ Lake Fortuna } & \multicolumn{4}{|c|}{ Grand Isle } \\
\hline & & & Preref. & Postref. & Prereef & Postreef & Preref. & Postref. & Prereef & Postreef & Preref. & Postref. & Prereef & Postreef \\
\hline Carcharhinus leucas & Bull shark & 102 & . & $2(1.0)$ & . & $1(0.0)$ & . & $1.3(0.3)$ & . & $22.3(20.9)$ & . & . & . & . \\
\hline Ariopsis felis & Hardhead catfish & 63 & . & 1.0 & . & 1.0 & $1.5(0.5)$ & $2.8(0.9)$ & 1.0 & $3.0(1.3)$ & 1.0 & $1.6(0.3)$ & . & $1.2(0.2)$ \\
\hline Callinectes sapidus & Blue crab & 22 & . & . & . & 1.0 & . & . & . & $1.5(0.5)$ & . & $1.2(0.2)$ & . & $1.7(0.3)$ \\
\hline Brevoortia patronus & Gulf menhaden & 16 & 3.0 & . & 2.0 & . & . & . & . & . & . & $1.0(0.0)$ & . & $4.5(0.5)$ \\
\hline Bagre marinus & Gaftopsail catfish & 13 & . & . & $1(0.0)$ & 1.0 & . & . & . & . & . & $1.0(0.0)$ & . & $1.2(0.2)$ \\
\hline Cynoscion nebulosus & Spotted seatrout & 12 & . & . & . & . & . & $1(0.0)$ & . & 1.0 & . & $1.5(0.5)$ & . & $1.2(0.2)$ \\
\hline Mugil cephalus & Striped mullet & 12 & . & . & . & . & . & . & . & . & . & $1.5(0.5)$ & . & $3(1.0)$ \\
\hline $\begin{array}{l}\text { Archosargus } \\
\text { probatocephalus }\end{array}$ & Sheepshead & 9 & . & . & . & . & . & 1.0 & . & . & . & 1.0 & . & $2.3(1.3)$ \\
\hline Rhinoptera bonasus & Cownose ray & 7 & 1.0 & . & . & . & $1(0.0)$ & . & . & $1(0.0)$ & . & . & . & . \\
\hline Pogonias cromis & Black drum & 6 & . & . & . & . & . & 1.0 & . & 1.0 & 1.0 & . & . & 1.0 \\
\hline Dorosoma cepedianum & Gizzard shad & 4 & . & . & . & $1(0.0)$ & . & 1.0 & . & . & 1.0 & . & . & . \\
\hline Paralichthys lethostigma & $\begin{array}{l}\text { Southern } \\
\text { flounder }\end{array}$ & 3 & . & . & . & 1.0 & . & . & . & . & . & . & 1.0 & 1.0 \\
\hline Dasyatis americana & $\begin{array}{l}\text { Southern } \\
\text { stingray }\end{array}$ & 2 & . & 1.0 & . & . & . & . & . & . & . & 1.0 & . & . \\
\hline Atractosteus spatula & Alligator gar & 2 & . & . & . & 1.0 & . & . & . & . & . & . & . & 1.0 \\
\hline Carcharhinus limbatus & Blacktip shark & 1 & . & . & 1.0 & . & . & . & . & . & . & . & . & . \\
\hline Peprilus alepidotus & harvestfish & 1 & . & . & . & . & . & 1.0 & . & . & . & . & . & . \\
\hline Sciaenops ocellatus & Red drum & 1 & . & . & . & . & . & . & . & . & . & 1.0 & . & . \\
\hline Scomberomorus maculates & $\begin{array}{l}\text { Spanish } \\
\text { mackerel }\end{array}$ & 1 & . & . & . & . & . & 1.0 & . & . & . & . & . & . \\
\hline Caranx hippos & Crevalle jack & 1 & . & . & . & . & . & . & . & . & . & . & . & 1.0 \\
\hline
\end{tabular}




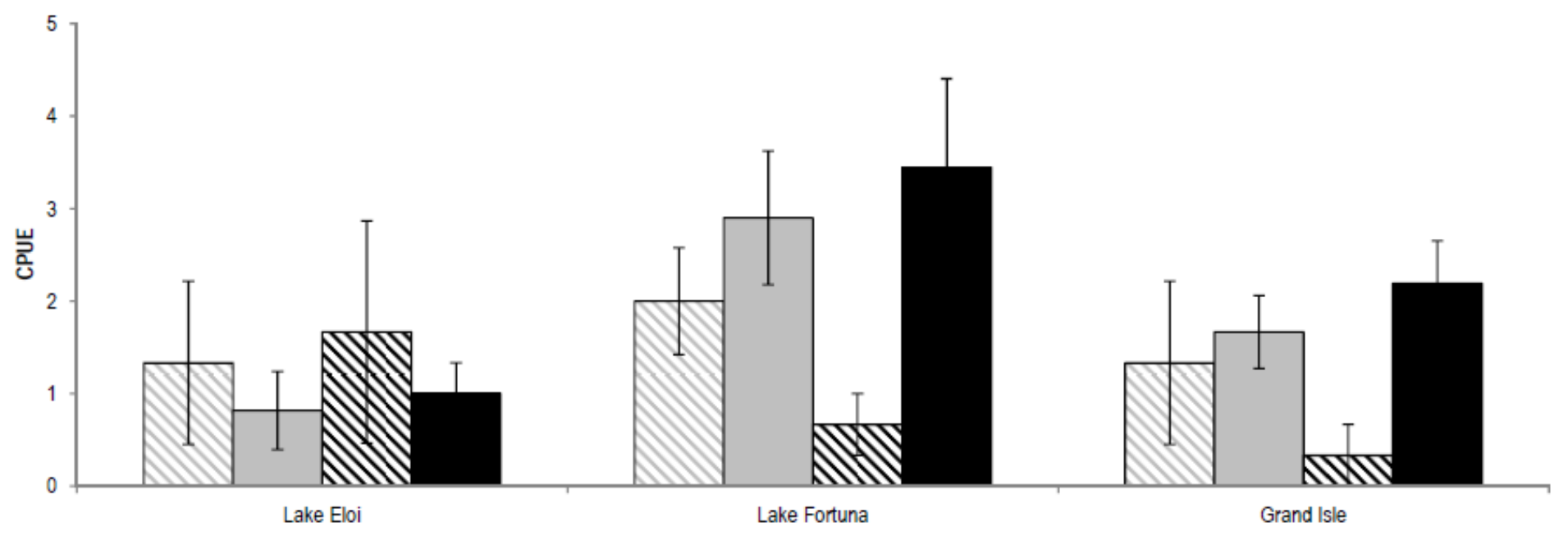

$\square$ Preconstruction- reference $\quad$ PPostconstruction- reference QPreconstruction - reef $\quad$ Postconstruction - reef Bars represent standard error.

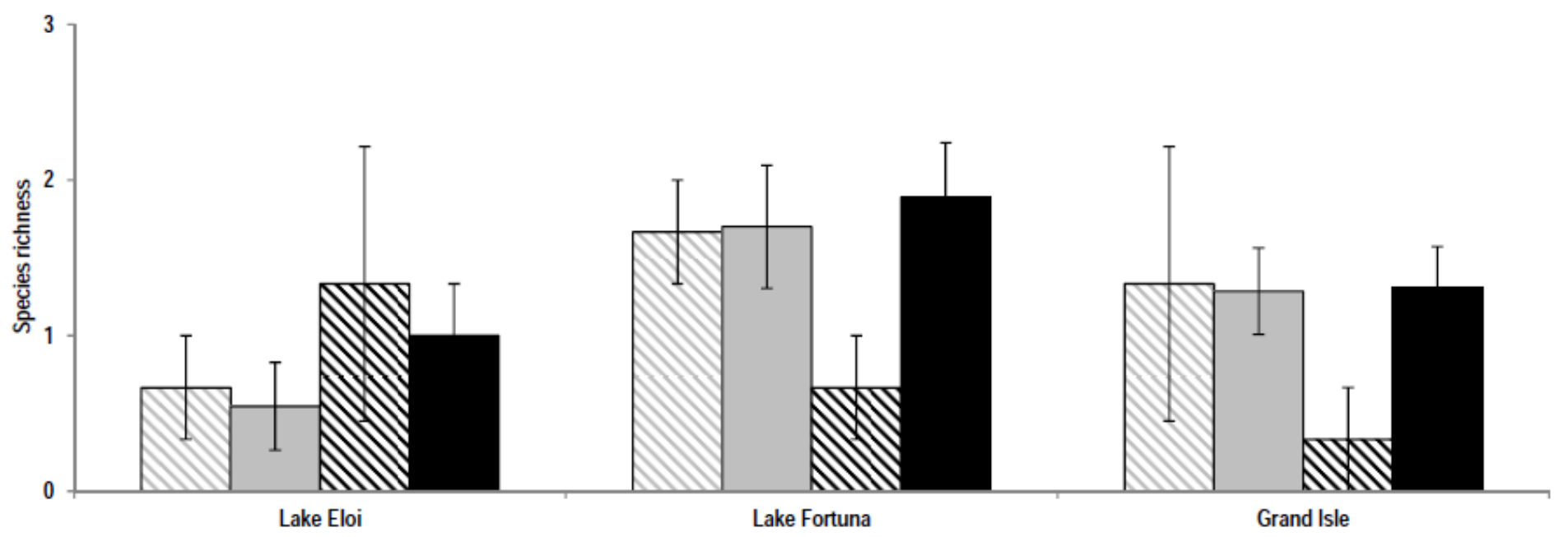

Figure 11. Graphs showing the gill net CPUE (SE) and species richness (SE) at Lake Eloi, Lake Fortuna, and Grand Isle sites. Each site had one preconstruction sampling event. Grand Isle has a total of 6 postconstruction sampling events, and Lake Eloi and Lake Fortuna each have 3 postconstruction sampling events.

Overall, 450 cast net samples were collected across all three sites from February 2010 to July 2012. In total, 2,708 individuals, consisting of 32 species of fish and invertebrates were collected (table 4). The most abundant organism was bay anchovy (Anchoa mitchilli), accounting for 38.3 percent of the catch by abundance, followed by B. patronus, which accounted for 23.4 percent of the total catch by abundance. Eighty-five percent of the total catch by abundance consisted of five species (bay anchovy [Ancho mitchilli], B. patronus, brown shrimp [Farfantepenaeus aztecus], grass shrimp [Palaemonetes pugio], and inland silverside [Menidia beryllina]). 
Table 4. Cast net total species catch and mean and standard error catch per unit effort (CPUE) for each Louisiana site. Lakes Eloi and Fortuna preconstruction data represent combined spring 2010 and summer 2011 samples; postconstruction samples represent winter, spring, and summer 2012 samples. Grand Isle preconstruction data represent combined spring and fall 2010 samples; postconstruction data represent combined spring and summer 2011 and 2012 samples. Data are presented only for baseline data information.

[N = 642 throws; 11 sampling events; total captured = 2,708 organisms; period (.), "0" catch; Preref., Preconstruction reference sites; Postref., Postconstruction reference sites; Prereef, Preconstruction reef sites; Postreef, postconstruction reef sites]

\begin{tabular}{|c|c|c|c|c|c|c|c|c|c|c|c|c|c|c|}
\hline \multirow[b]{2}{*}{ Species } & \multirow[b]{2}{*}{ Common name } & \multirow[b]{2}{*}{ Total } & \multicolumn{4}{|c|}{ Lake Eloi } & \multicolumn{4}{|c|}{ Lake Fortuna } & \multicolumn{4}{|c|}{ Grand Isle } \\
\hline & & & Preref. & Postref. & Prereef & Postreef & Preref. & Postref. & Prereef & Postreef & Preref. & Postref. & Prereef & Postreef \\
\hline Anchoa rmitchi糗 & Bay anchory & 1047 & $3.3(1.3)$ & $1.3(0.3)$ & & 1.0 & & $2.7(1.2)$ & $3.3(1.0)$ & $2.3(1.3)$ & & $9.3(2.8)$ & $17.5(13.3)$ & $36.3(27.1)$ \\
\hline Brevoortia patronus & Guff menhaden & 640 & 1.0 & 27.0 & $61.0(49.0)$ & & 2.0 & & $54.8(26.9)$ & & $6.5(0.5)$ & $1.3(0.3)$ & 2.0 & $31.1(15.9)$ \\
\hline Fafartepenaeus aztecus & Brown shimp & 300 & $3.4(0.6)$ & $1.2(0.2)$ & $4.2(0.9)$ & $1.0(0.0)$ & $6.2(1.9)$ & $1.2(0.2)$ & $3.6(0.9)$ & $1.5(0.3)$ & & $1.7(0.3)$ & . & $2.5(0.8)$ \\
\hline Palaernoretes puggio & Grass shrimp & 288 & $3.6(1.5)$ & $3.4(1.0)$ & $1.8(0.4)$ & $2.2(1.2)$ & $4.8(1.3)$ & $3.7(2.7)$ & $2.0(0.5)$ & $5.5(4.5)$ & $9.5(4.6)$ & $5.0(2.6)$ & $2.3(0.9)$ & \\
\hline Menidia berylinina & Inland silverside & 133 & 1.0 & $3.5(1.2)$ & 1.0 & $4.4(1.4)$ & $4.8(2.3)$ & $1.7(0.5)$ & $3.0(0.0)$ & $1.0(0.0)$ & $1.0(0.0)$ & $4.3(3.3)$ & $1.0(0.0)$ & $1.2(0.2)$ \\
\hline Litopenaaus setiferus & White shite & 60 & $1(0.0)$ & $12.3(9.6)$ & & & & & & 2.0 & . & $1.0(0.0)$ & . & $1.3(0.3)$ \\
\hline Merntras martinica & Rough silverside & 51 & & $1.0(0.0)$ & 1.0 & $2.5(0.6)$ & $1.0(0.0)$ & $8.3(4.3)$ & 5.0 & - & & 4.0 & . & $1.0(0.0)$ \\
\hline Mugiil cephalus & Striped mullet & 38 & $1.0(0.0)$ & $1(0.0)$ & & 1.0 & . & & & $1.4(0.4)$ & . & $1.5(0.4)$ & $1.0(0.0)$ & $1.3(0.3)$ \\
\hline Anchoa hepsetu & Striped anchovy & 19 & & 1.0 & & & . & 1.0 & 7.0 & . & & $1.6(0.2)$ & & $1.0(0.0)$ \\
\hline Leiostamus xarthurus & Spot & 19 & 1.0 & & & & . & & 6.0 & . & 3.0 & $1.0(0.0)$ & 3.0 & $1.5(0.5)$ \\
\hline Fundulus gandis & Guff killifish & 14 & & & & 2.0 & 2.0 & $4.5(3.5)$ & & . & & . & 1.0 & \\
\hline Fundulus similis & Longnose killifish & 13 & & $1(0.0)$ & . & - & & $1.3(0.3)$ & & 1.0 & $2.0(1.0)$ & & 2.0 & . \\
\hline Lagodon mornboides & Pinfish & 13 & . & . & . & 1.0 & & 1.0 & . & & . & $1.2(0.2)$ & & $1.0(0.0)$ \\
\hline Mcropogonias undulatus & Atlantic croaker & 13 & . & . & . & - & & 1.0 & & & & $1.0(0.0)$ & & $1.0(0.0)$ \\
\hline Bairdialla chrysaura & Silver perch & 12 & 1.0 & $1(0.0)$ & . & 1.0 & & - & & $1.0(0.0)$ & & $1.0(0.0)$ & & $1.3(0.3)$ \\
\hline Pornatomas salatrix & Bluefich & 12 & . & 11.0 & . & - & 1.0 & . & & . & & . & & - \\
\hline Cynoscion arenarius & Sanatrout & 5 & $1.3(0.3)$ & - & . & & . & . & & & & 1.0 & & . \\
\hline Oligoplites sauris & Leatherjack & 5 & - & . & . & & & 1.0 & & & & $2.0(1.0)$ & & . \\
\hline Trachinotus carolinus & Florida pompano & 5 & . & . & . & . & & - & . & & & 2.0 & & 3.0 \\
\hline Alosa chrysochloris & Skipjack herring & 3 & . & . & . & . & & . & 3.0 & & & & & - \\
\hline Callinectes sapidus & Blue crab & 3 & . & 1.0 & . & . & & . & - & & & 1.0 & & 1.0 \\
\hline Sphogroides parvus & Least puffer & 3 & . & - & . & . & 1.0 & & $1.0(0.0)$ & & & . & & \\
\hline Sciaenops occelatus & Red dum & 2 & . & . & . & . & . & . & 1.0 & 1.0 & & & & . \\
\hline Scianeidae & Unk. drum & 2 & 1.0 & . & . & & & . & . & . & & & 1.0 & . \\
\hline Caranx hippos & Crevalle jack & 1 & - & . & . & . & & . & . & & & 1.0 & & . \\
\hline Clupeidae & Unk. herring & 1 & . & . & . & & & . & & & & & & 1.0 \\
\hline Eurypanqueus abbreviatus & Lobate mud crab & 1 & & & & & . & & & . & 1.0 & . & . & \\
\hline Etropus coossotus & Fringed founder & 1 & & 1.0 & & & . & & & . & . & . & . & \\
\hline Eurypancpeus depressus & Depressed mud crab & 1 & & & & 1.0 & . & & & . & . & . & . & \\
\hline Pogorias coornis & Black drum & 1 & 1.0 & & & & . & & & . & . & . & . & \\
\hline Paralichutiys lethos tigma & Southem flounder & 1 & & & & & . & & & . & . & . & . & 1.0 \\
\hline Strongytura marina & Atlantic needefish & 1 & & & & & . & & & . & . & . & . & 1.0 \\
\hline
\end{tabular}


Overall, CPUE and richness of cast net samples were similar at each site between treatments (fig. 12). Only Lake Fortuna had a significant effect of construction status for CPUE $(p=0.007)$, with a reduction of CPUE at both reef and reference sites postconstruction. This reduction is likely not related to the construction of the reef and is more likely a reflection of the timing of the sample events. Individual species comparisons of the most abundant organisms from postconstruction samples only revealed no differences in abundance by treatment (student's t-test; $\mathrm{p}>0.05)$.
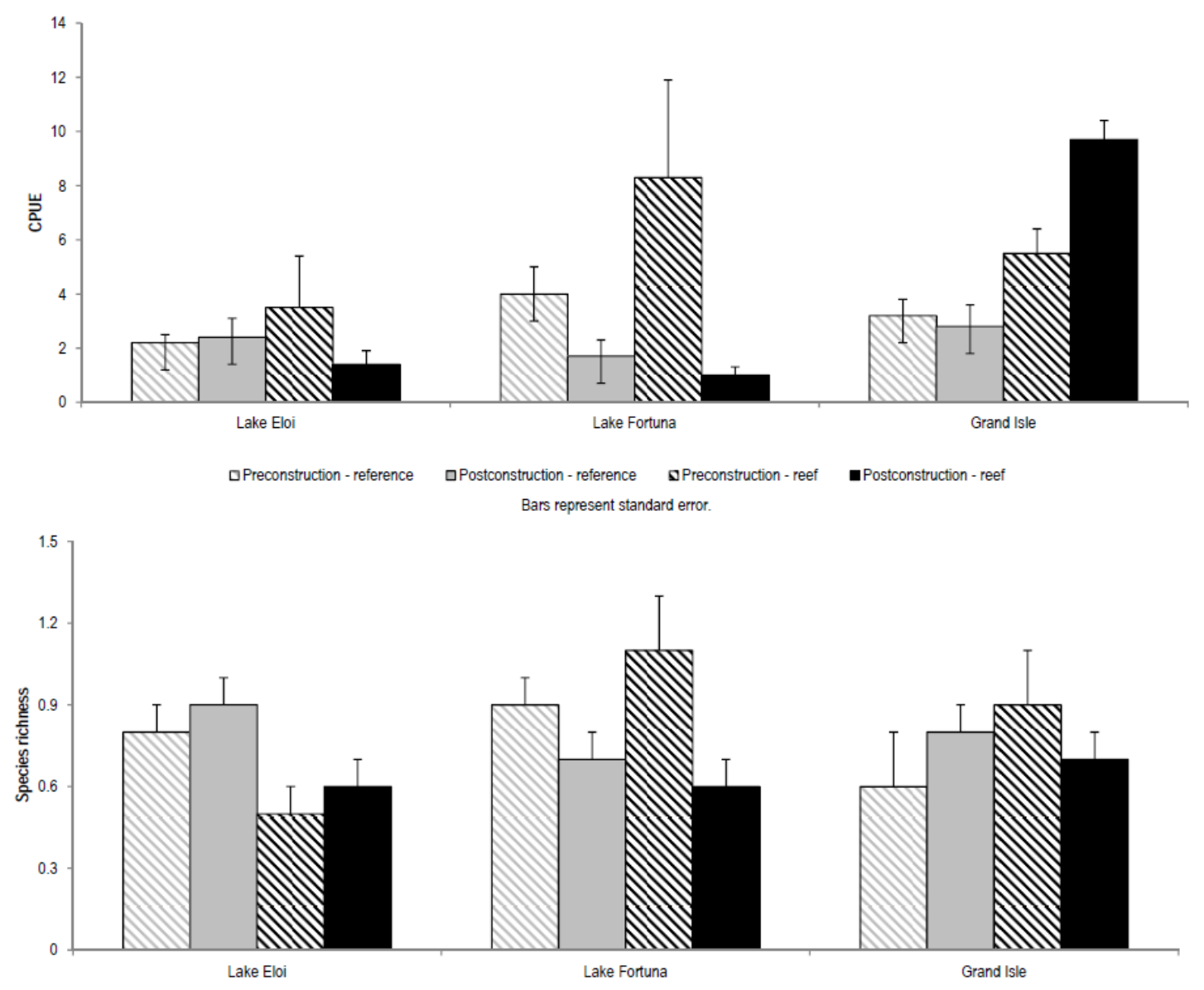

Figure 12. Graphs showing the cast net CPUE (SE) and species richness (SE) at Lake Eloi, Lake Fortuna and Grand Isle sites. Each site has a total of 2 preconstruction sample events. Grand Isle has a total of 5 postconstruction sample events and Lakes Eloi and Fortuna have 3 postconstruction sample events.

CPUE from seines at reef sites was greater than at reference sites, but this difference was only statistically different at Lake Fortuna and Lake Eloi reefs ( $p=0.05$ ) (fig. 13, table 5). Species richness at Lakes Eloi and Fortuna was higher at reef sites than nonreef sites; however, this difference was statistically significant at Lake Eloi only $(\mathrm{p}<0.0001)$. Biomass was similar across all sites and treatments (figure 13). Preconstruction sampling included one winter and one summer sample for all sites and thus should be interpreted with caution. Individual species comparisons of the most abundant organisms from postconstruction samples only revealed no differences in abundance by treatment (student's t-test; $\mathrm{p}>0.05$ ). 
Table 5. Seine total species catch and mean (standard error) catch per unit effort (CPUE) for each Louisiana site. Lakes Eloi and Lake Fortuna preconstruction data represent combined spring 2010 and summer 2011 samples; postconstruction samples represent winter, spring, and summer 2012 samples. Grand Isle preconstruction data represent combined spring and fall 2010 samples; postconstruction data represent combined spring and summer 2011 and 2012 samples. Data are presented only for baseline data information.

[N = 227 seine pulls; 11 sampling events; total captured = 6,625 organisms; period (.), "0" catch; Preref., Preconstruction reference sites; Postref., Postconstruction reference sites; Prereef, Preconstruction reef sites; Postreef, postconstruction reef sites]

\begin{tabular}{|c|c|c|c|c|c|c|c|c|c|c|c|c|c|c|}
\hline \multirow[b]{2}{*}{ Species } & \multirow[b]{2}{*}{ Common name } & \multirow[b]{2}{*}{ Total } & \multicolumn{4}{|c|}{ Lake Eloi } & \multicolumn{4}{|c|}{ Lake Fortuna } & \multicolumn{4}{|c|}{ Grand Isle } \\
\hline & & & Preref. & Postref. & Prereef & Postreef & Preref. & Postref. & Prereef & Postreef & Preref. & Postref. & Prereef & Postreef \\
\hline Anchoa rmitchilli & Bay anchowy & 3520 & $5.7(2.7)$ & $29.2(9.9)$ & $32.8(20.2)$ & $48.3(22.6)$ & $6.6(2.7)$ & $102.0(63.4)$ & $5(2.3)$ & $5.2(2.5)$ & $13.0(5.7)$ & $26.5(7.8)$ & $89.2(50.0)$ & $26.5(10.5)$ \\
\hline Bevoortia patronus & Gulf menhaden & 840 & . & 38 & 3 & $2.0(1.0)$ & 4 & . & . & & & $7.9(4.1)$ & . & $88.0(54.5)$ \\
\hline Palaernonetes pugio & Grass shrimp & 670 & $3.3(1.9)$ & $5.4(2.2)$ & $11.3(7.4)$ & $8.8(2.1)$ & $4.7(3.2)$ & $34.9(31.9)$ & $5.8(2.8)$ & $8.3(7.3)$ & . & $6.9(3.4)$ & & $2.7(0.6)$ \\
\hline 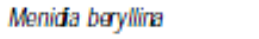 & Inland silverside & 544 & 2 & $5.5(4.5)$ & & $7.5(3.5)$ & 1 & 7 & $1.5(0.5)$ & $6.3(4.6)$ & . & $8.4(6.9)$ & 1 & $18.9(6.5)$ \\
\hline Mernbras martinica & Rough silverside & 303 & 4 & $22.7(20.7)$ & & $8.0(6.0)$ & & $52.3(28.3)$ & 2 & $20(0.0)$ & & & . & . \\
\hline Farfantepenaaus aztecus & Brown shrimp & 182 & $1.0(0.0)$ & $2.0(1.0)$ & 1 & $1.3(0.3)$ & $1.0(0.0)$ & $1.7(0.4)$ & & 1 & & $5.0(1.4)$ & . & $7.7(2.6)$ \\
\hline Cynoscion arenarius & Sandtrout & 125 & & $29.5(27.5)$ & & $4.5(1.4)$ & . & $11.0(5.5)$ & & $23(0.7)$ & . & 1 & & $1.8(0.5)$ \\
\hline Anchoa hepseus & Striped anchowy & 121 & & $4.0(0.0)$ & & & . & $7.3(5.6)$ & & $20(1.0)$ & . & $8.9(7.3)$ & & $1.5(0.3)$ \\
\hline Bairdiella clrysoura & Silver perch & 80 & & 1 & & $3.5(2.5)$ & . & 1 & 1 & . & . & $2.0(0.7)$ & & $6.2(1.1)$ \\
\hline Alosa chrysochloris & Skipjack herring & 78 & . & . & 3 & . & & & & & & $24.7(9.8)$ & . & 1 \\
\hline Litopenaeus setuferus & White shrimp & 46 & . & . & & 1 & 5 & & & & & & . & $13.3(10.4)$ \\
\hline Mugil cephalus & Striped mullet & 22 & & & & & . & & & $3.0(0.0)$ & . & $2.8(1.6)$ & 2 & \\
\hline Oigoplites saurus & Leatherjack & 15 & & $1.3(0.3)$ & & 1 & 1 & 1 & & . & . & $1.3(0.3)$ & 1 & $1.0(0.0)$ \\
\hline Miropogonias unduatus & Atlantic croaker & 15 & & & & & & & & & & $2.7(1.2)$ & & $3.5(2.5)$ \\
\hline Calininectes sapidus & Blue crab & 8 & . & . & & . & 1 & 1 & & 1 & & 1 & . & $1.0(0.0)$ \\
\hline Elops saurus & Ladyfish & 8 & . & $2.5(0.5)$ & & 1 & & & & & & 1 & . & 1 \\
\hline Leiostornus xanthurus & Spot & 8 & & & & & . & & & . & . & $3.5(2.5)$ & & 1 \\
\hline Lagodon rhomboides & Pinfish & 7 & & 1 & 1 & 1 & . & & & . & . & 3 & 1 & \\
\hline Caranx hippos & Crevalle jack & 6 & & & & & & & & & . & $2.5(1.5)$ & & 1 \\
\hline Gobiesox strumosus & Skiletiish & 6 & . & 1 & & $2.5(1.5)$ & & & & & & & . & . \\
\hline Clupeidae $s p$. & Unk. herring & 5 & & & $2.5(1.5)$ & - & . & & & & . & . & & \\
\hline Funduius similies & Longnose killifish & 3 & & & & & 2 & & & . & . & 1 & & \\
\hline Synodis foeters & Inshore lizardfish & 3 & & & & & . & 1 & & & . & 2 & & \\
\hline Sirongyiura marina & Atlantic needlefish & 2 & & & & & 1 & & & & & 1 & & \\
\hline Adinia Xerica & Diamond killifish & 1 & . & . & 1 & . & & & & & & & . & . \\
\hline Eurypanopeus depressis & Depressed mud crab & 1 & & & & & . & & & & . & 1 & & \\
\hline Hyporhamphus meeki & American halfbeak & 1 & & & & & . & & & . & . & 1 & & \\
\hline Pomatomas salautix & Bluefish & 1 & & & & 1 & . & & & & . & . & & \\
\hline Syngrathus scovelif & Gulf pipefish & 1 & . & - & & - & & & & & & 1 & . & . \\
\hline Rhiutroparopaeus harrisï & Xanthid mud crab & 1 & . & & & & & . & . & & & . & . & 1 \\
\hline Gobiosoma bosc & Naked goby & 1 & & & & 1 & & & & & . & . & & \\
\hline Pogonias cromis & Black drum & 1 & & 1 & & & . & & & . & . & . & & \\
\hline
\end{tabular}



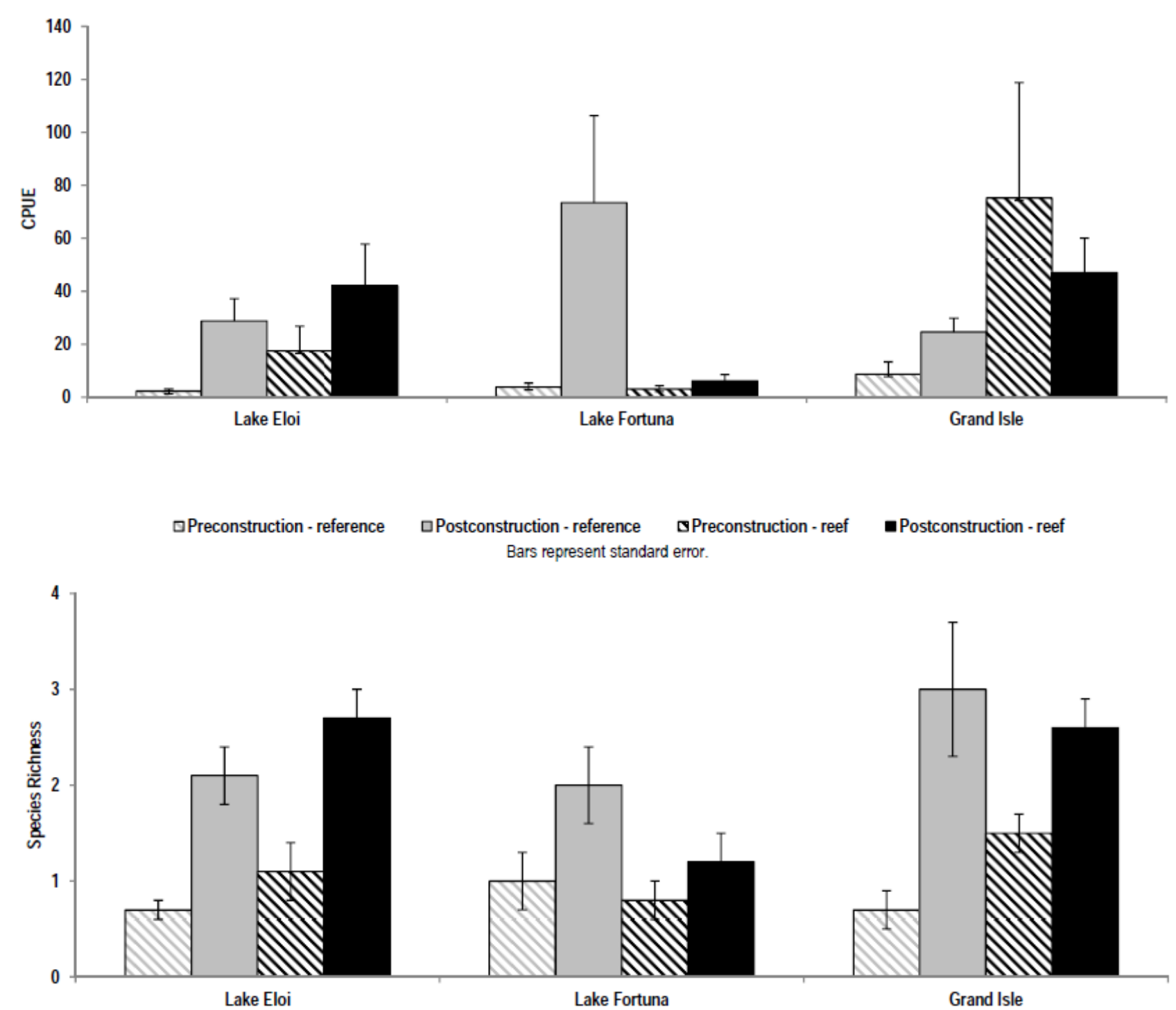

Figure 13. Graphs showing the seine CPUE (SE) and species richness (SE) at Lake Eloi, Lake Fortuna, and Grand Isle sites. Each site has a total of 2 preconstruction sample events. Grand Isle has a total of 5 postconstruction sample events and Lakes Eloi and Fortuna have 3 postconstruction sample events.

Each sample event involves $210-\mathrm{m}$ seine pulls adjacent to the treatment site at the triplicate sites located at each reef and reference siteFrom 180 seine pulls, there were a total of 6,625 individuals, consisting of 31 species of fish and invertebrates across sites and treatments (table 5). The most abundant organisms were bay anchovy (A. mitchilli) and B. patronus, accounting for 53.1 percent and 12.7 percent, respectively, of the total catch by abundance. Eighty-nine percent of the total catch consisted of 5 species (A. mitchilli, B. patronus, P.pugio, M. beryllina, and Membras martinica [rough silverside]).

In total, 3,641 individuals, composed of 23 species, were collected from trays deployed in Grand Isle and Lake Fortuna (table 6, 7). Of that, 1,224 individuals were collected from Lake Fortuna trays in 2012, and 2,417 were collected from Grand Isle (combined 2011 and 2012). 
Trays were used to characterize and evaluate the presence of smaller fish and invertebrate species that are known to use reef systems and may provide forage food for medium and large fish and invertebrates that frequent the reefs. A total of 22 species were collected in Grand Isle trays, and 11 species were collected in Lake Fortuna trays. The trays indicated the presence of known reef resident and reef dependent species such as small mud crabs (for example, $R$. harrissi, E. depressus, M. adina), gobies (for example, G. boleosoma), and toadfish (O. beta).

Table 6. Grand Isle, Louisiana, tray data from 2011 and 2012 combined ( $N=33)$. Total number is the count of each species; density is the number of individuals per meter squared (standard error).

\begin{tabular}{|llc|c|}
\hline Species & Common name & Total & Density (individuals m-2) \\
\hline Palaemonetes pugio & Grass shrimp & 1172 & $166.5(33.0)$ \\
Callinectes sapidus & Blue crab & 423 & $62(10.4)$ \\
Alpheus sp. & Snapping shrimp & 168 & $27.3(6.0)$ \\
Eurypanopeus depressus & Depressed mud crab & 134 & $25.4(4.8)$ \\
Clibanarius vittatus & Thinstripe hermit crab & 260 & $51.4(12.6)$ \\
Gobiosoma bosc & Naked goby & 83 & $18.9(4.3)$ \\
Gobionellus boleosoma & Darter goby & 77 & $19.4(3.4)$ \\
Rhithropanopeus harrisii & Harris mud crab & 48 & $15.6(3.6)$ \\
Menippe adina & Gulf stone crab & 16 & $9.1(1.5)$ \\
Menippe mercenaria & Florida stone crab & 3 & $4.5(0.0)$ \\
Myrophis punctatus & Speckled worm-eel & 6 & $9.1(4.5)$ \\
Opsanus beta & Gulf toadfish & 3 & $4.5(0.0)$ \\
Panopeus simpsoni & Oystershell mud crab & 3 & $4.5(0.0)$ \\
Petrolisthes armatus & Green porcelain crab & 4 & $6.1(1.5)$ \\
Litopenaeus setiferus & White shrimp & 3 & $6.8(2.3)$ \\
Xanthidae & Mud crab & 6 & $13.6(4.5)$ \\
Chasmodes bosquianus & Striped blenny & 1 & 4.5 \\
Chaetodipterus faber & Spadefish & 1 & 4.5 \\
Farfantopenaeus aztecus & Brown shrimp & 1 & 4.5 \\
Gobiesox strumosus & Skilletfish & 2 & 9.1 \\
Hypsoblennius hentzi & Feathered blenny & 1 & 4.5 \\
Lutjanus griseus & Mangrove snapper & 2 & 9.1 \\
\hline & Total & 2,417 & $332.9(35.4)$ \\
\hline
\end{tabular}


Table 7. Lake Fortuna, Louisiana, tray data from $2012(\mathrm{~N}=12)$. Density is the number of individuals per meter squared (standard error).

\begin{tabular}{|c|c|c|c|}
\hline Species & Common name & Total & Density (individuals $\mathrm{m}^{-2}$ ) \\
\hline Palaemonetes pugio & Grass shrimp & 625 & $236.7(44.6)$ \\
\hline Rhirthropanaeus harrisii & Harris mud crab & 304 & $115.2(29.7)$ \\
\hline Gobiosoma bosc & Naked goby & 95 & $43.2(18.3)$ \\
\hline Callinectes sapidus & Blue crab & 85 & $32.2(6.6)$ \\
\hline Eurypanopeus depressus & Depressed mud crab & 73 & $33.2(7.3)$ \\
\hline Gobiesox strumosus & Skilletfish & 18 & $10.2(2.1)$ \\
\hline Alpheus sp. & Snapping shrimp & 10 & $7.6(2.2)$ \\
\hline Gobionellus boleosoma & Darter goby & 7 & $10.6(4.0)$ \\
\hline Menippe adina & Gulf stone crab & 3 & $4.5(0.0)$ \\
\hline Opsanus beta & Gulf toadfish & 3 & $6.8(2.3)$ \\
\hline \multirow[t]{2}{*}{ Bairdiella chrysoura } & Silver perch & 1 & 4.5 \\
\hline & Total & 1,224 & $448.3(63.8)$ \\
\hline
\end{tabular}

Mean density of species collected at Lake Fortuna and Grand Isle were higher than any previously reported in the literature (Lake Fortuna: $448.3 \pm 63.8$ ind $\mathrm{m}^{-2}$; Grand Isle: $332.9 \pm$ $35.4 \mathrm{ind} \mathrm{m}^{-2}$ ) and indicated rapid colonization and recruitment to the reef area (table 6,7). In 2010 , by using the same trays on subtidal oyster reefs across coastal Louisiana, a mean density of $276.8 \pm 15.3 \mathrm{ind} \mathrm{m}^{-2}$ was calculated (Beck, 2011). These samples were taken from subtidal reefs, with half being taken in areas that are regularly harvested for oysters. Other published information on benthic communities was not as directly comparable because of slight differences in gear use, including the lack of an enclosure net. For example, Plunket and La Peyre (2005) used open trays to sample harvested oyster leases in Barataria Bay, La., and reported lower densities of fish (13.9 ind $\mathrm{m}^{-2}$ ) and invertebrates $\left(168.4 \mathrm{ind} \mathrm{m}^{-2}\right)$ than this study. Other tray studies (Tolley and Volety, 2005) and drop sampling studies (Shervette and Gelwick, 2008; Stunz and others, 2010) on other oyster reefs in the northern Gulf of Mexico also reported lower densities than those found in the present study.

\section{Summary and Conclusions}

Measurement of the shoreline protection services, reef sustainability, water quality, and habitat enhancement functions of three created reefs in Grand Isle, Lake Eloi, and Lake Fortuna, Louisiana successfully occurred following creation of these reefs. Unfortunately, a large oil spill, and concomitant significant construction delays, resulted in a significantly reduced monitoring timeframe at all three sites (approximately 17 months at Grand Isle and 9 months at Lakes Eloi and Fortuna). Similarly, the discordance of construction schedules reduced our ability to compare across sites within such a short timeframe and affected the data analysis that we were able to complete. Since all ecosystem services and the development of reef communities are predicted to occur over a long timeframe, reef monitoring could be continued for several more years in order to fully evaluate the services provided.

The primary goal of this reef creation project was to create sustainable reefs to reduce shoreline erosion. This project collected baseline information on recruitment for 8 (Lakes Eloi and Fortuna) and 18 (Grand Isle) months postcreation; because of high interannual variability in 
this region, and our inability to predict whether initial recruitment at Lakes Eloi and Fortuna will result in survival and existence of 1-year-old oysters in 2013, it is impossible to determine whether the reefs will be sustainable at these locations without more time to allow reef development. In contrast, Grand Isle reefs had two summer spawning seasons to recruit and grow oysters. Although we know that this area supports high oyster growth in cages, as evidenced by the Louisiana Sea Grant oyster hatchery located adjacent to the reef and by the good growth rates recorded in our caged oysters, the lack of live, large oysters on the reef, or on our minireef prototypes, "reefsicles," indicates low survival at this site. Selecting appropriate sites for the development of sustainable oyster reefs is critical and all potential causes of mortality and factors influencing growth on the oyster itself need to be considered when selecting sites.

It was hypothesized that these reef structures would act to reduce wave energies on the shoreline, accumulate sediment behind the reefs, and ultimately slow or stop shoreline retreat. Both Lake Fortuna and Lake Eloi reefs showed an immediate (8 months) positive effect on shoreline retreat after construction of the reefs was complete. Both areas had significantly high shoreline retreat rates in the almost 2 years of preconstruction monitoring that was completed, and the change postconstruction is striking. Further monitoring and measurement of shoreline slope changes is important for ensuring that this result is lasting and not because of local or regional weather events (for example, Hurricane Isaac) that occurred during this one 8-month period. In contrast, Grand Isle showed no effect of the reef placement on shoreline retreat rates, although transect surveys do indicate sediment accumulation behind the reefs. Continued monitoring to determine if shoreline protection may occur through the build-up of sediments behind the reefs as opposed to immediate postconstruction energy attenuation would be beneficial. Differences in reef placement (distance from shore) could also be further examined to determine if reef effects on shoreline stabilization reflect local site conditions (wind, wave), reef design (placement), or a combination of all factors.

Other associated ecosystem services hypothesized and predicted to develop over time with sustainable reefs include improvement of water quality and habitat enhancement. Water quality improvements may be because of reefs reducing wave energies to such an extent that water clarity behind the reef is greatly improved. We did not document any reef effects on water clarity immediately behind or adjacent to reefs. Alternatively, water quality improvements may occur due to the filtration abilities of oysters, which is a direct function of oyster density and size, water temperature, and salinity. None of the reefs at the end of the study had a significant oyster population established on the reefs. As the oyster communities develop, water quality effects may be expected to occur.

Habitat enhancement may occur, however, through the provision of structure initially provided by the artificial reef material. All of the sites did show that the reefs provided habitat for a number of fish and crustaceans. Reefs appeared to enhance the abundance of some important species including blue crab, anchovies, and gulf menhaden and failed to have an impact on larger, transient fish species, which is similar to findings from other studies (for example, Peterson and others, 2003; Geraldi and others, 2009; Scyphers and others, 2011; Yeager and Layman, 2011).

\section{Future Directions}

Placing reef structure materials in a location that will not recruit or support a sustainable oyster population will eventually lead to the loss of all structure at the site. Optimization of reef success as measured by oyster population response and reef services might be enhanced by some 
or all of the following considerations. Site criterion beyond basic salinity limits of oysters need to be expanded; possible predation related oyster mortality, local hydrodynamics, and site bathymetry should all be more closely evaluated. On a practical side, accurate methods to sample oyster populations on different types of reef bases within turbid waters need to be established to allow for comparison among projects. The use of off-reef experimental units (for example, reefsicles) would simplify future monitoring, allowing comparison of different reef construction materials, and allowing resampling and tracking of the same oyster populations. Shoreline erosion and movement processes should be examined more closely to better determine how the reefs may be affecting shoreline erosion rates. In particular, the placement of reefs in relation to distance from the shoreline, local water depths, wave energies, local sediment transport processes, and occurrence of erosive wind energies needs to be strongly considered and understood.

Guidelines are needed to accurately identify sites that are likely to support sustainable oyster reefs over the long term. Measurable system responses to reef establishment require more time than was available for this study; therefore, this study can easily serve as a baseline for long term monitoring that would be useful in assessing reef outcome and development trajectories and relating reef service provision to local site conditions. As the reefs develop, it is likely that effects of the reefs will be more evident and that other ecosystem services, such as water filtration, may begin to be measurable; it is also possible that the development of a sustainable benthic and bivalve community will have further effects on the nekton using the reef, and even more effects will be measured.

\section{Cited References}

Barras, J., Beville, S., Britsch, D., Hartley, S., Hawes, S., Johnston, J., Kemp, P., Kinler, Q., Martucci, A., Porthouse, J., Reed, D., Roy, K., Sapkota, S., and Suhayda, J., 2004, Historical and projected coastal Louisiana land changes-1978-2005: USGS Open File Report 03-334, 39 p. (Revised January 2004.)

Beck, S., 2011, The effects of oyster harvest on resident oyster reef communities and reef structure in coastal Louisiana: Baton Rouge, Louisiana State University, M.S. thesis.

Coen, L.D., Luckenbach, M.W., and Breitburg, D.L., 1999, The role of oyster reefs as essential fish habitat-A review of current knowledge and some new perspectives, in Benaka, L.R., ed., Fish habitat-Essential fish habitat and restoration: American Fisheries Society Symposium, v. 22, p. 438-454.

Coen, L.D., Brumbaugh, R.D., Bushek, D., Grizzle, R., Luckenbach, M.W., Posey, M.H., Powers, S.P., and Tolley, S.G., 2007, Ecosystem services related to oyster restoration: Marine Ecology Progress Series, v. 341, p. 304-307.

Geraldi, N.R., Powers, S.P., Heck, K.L., Jr., and Cebrian, J., 2009, Can habitat restoration be redundant? Response of mobile fishes and crustaceans to oyster reef restoration in marsh tidal creeks: Marine Ecology Progress Series, v. 389, p. 171-180.

Lehnert, R.L., and Allen, D.M., 2002, Nekton use of subtidal oyster shell habitat in a southeastern U.S. estuary: Estuaries, v. 25, p. 1015-1024.

Meyer, D.L., Townsent, E.C., and Thayer, G.W., 1997, Stabilization and erosion control value of oyster cultch for intertidal marsh: Restoration Ecology, v. 5, p. 93-99.

Peterson, C.H., Grabowski, J.H., and Powers, S.P., 2003, Estimated enhancement of fish production resulting from restoring oyster reef habitat-Quantitative valuation: Marine Ecology Progress Series, v. 264, p. 251-266. 
Piazza, B.P., Banks, P.D., and La Peyre, M.K., 2005, The potential for created oyster shell reefs as a sustainable shoreline protection strategy in Louisiana: Restoration Ecology, v. 13, p. 499506.

Plunket, J.T., and La Peyre, M.K., 2005, Oyster beds as fish and macroinvertebrate habitat in Barataria Bay, Louisiana: Bulletin of Marine Science, v. 77, p. 155-164.

Scyphers, S.B., Powers, S.P., Heck, K.L., Jr., and Byron, D., 2011, Oyster reefs as natural breakwaters mitigate shoreline loss and facilitate fisheries: PLoS ONE, v. 6, p. e22396.

Shervette, V.R., and Gelwick, F., 2008, Seasonal and spatial variations in fish and macroinvertebrate communities of oyster and adjacent habitats in a Mississippi estuary: Estuaries and Coasts, v. 31, p. 584-596.

Stunz, G.W., Minello, T., and Rozas, L., 2010, Relative value of oyster reef as habitat for estuarine nekton in Galveston Bay, Texas: Marine Ecology Progress Series, v. 406, p. 147159.

Supan, J.E., and Wilson, C.A., 2001, Analyses of gonadal cycling by oyster broodstock, Crassostrea virginica (Gmelin), in Louisiana: Journal of Shellfish Research, v. 20, p. 215-220.

Tolley, G., and Volety, A.K., 2005, The role of oysters in habitat use of oyster reefs by resident fishes and decapod crustaceans: Journal of Shellfish Research, v. 24, p. 1007-1012.

Yeager, L.A., and Layman, C.A., 2011, Energy flow to consumers in a sub-tropical oyster reef food web: Aquatic Ecology, v. 45, no. 2, p. 267-277. 